\title{
OVER LAND AND OVER SEA
}

DOMESTIC TRADE FRICTIONS IN THE PHILIPPINES

Eugenia Go

NO. 611

February 2020
ADB ECONOMICS WORKING PAPER SERIES 


\section{ADB Economics Working Paper Series}

\section{Over Land and Over Sea: Domestic Trade Frictions in the Philippines}

\section{Eugenia Go}

No. 611 | February 2020
Eugenia Go (ego@adb.org) is an economics officer in the Economic Research and Regional Cooperation Department of the Asian Development Bank (ADB).

An earlier version of this work was published as a University of Sussex Economics Working Paper. For this revised version, the author gratefully acknowledges the guidance of Ingo Borchert and L. Alan Winters in conducting this study. The author also benefited from the comments from the faculty of the Department of Economics of the University of Sussex. In ADB, Benno Ferrarini, Rana Hasan, and Yasuyuki Sawada read an earlier draft and offered extensive comments. Acknowledgments are due to organizations that provided access to information and data including the House of Representatives, the Department of Agriculture, the Maritime Industry Authority, the Philippine Ports Authority, the Philippine Statistical Authority, and the Development Bank of the Philippines. The following shipping companies contributed to the data gathering survey: 2Go Group, Archipelago Ferries, Atienza, Daima Shipping, Eastern Pacific, EB Aznar, FF Cruz, Gabisan, George and Peter Lines, GT Express, Kalayaan, Lorenzo, Maayo, Medallion, Montenegro, Philippine Span Asia, Peñafrancia, Philharbor, Philstone, Regina, Roble, Santa Clara, Tri-Star Megalink, and VG Shipping. The author thanks Christopher Nietes, Samantha Nietes, and Lurilyn Duya for data collection and encoding. 
(C) 2020 Asian Development Bank 6 ADB Avenue, Mandaluyong City, 1550 Metro Manila, Philippines

Tel +632 8632 4444; Fax +63286362444

www.adb.org

Some rights reserved. Published in 2020.

ISSN 2313-6537 (print), 2313-6545 (electronic)

Publication Stock No. WPS200080-2

DOI: http://dx.doi.org/10.22617/WPS200080-2

The views expressed in this publication are those of the authors and do not necessarily reflect the views and policies of the Asian Development Bank (ADB) or its Board of Governors or the governments they represent.

ADB does not guarantee the accuracy of the data included in this publication and accepts no responsibility for any consequence of their use. The mention of specific companies or products of manufacturers does not imply that they are endorsed or recommended by ADB in preference to others of a similar nature that are not mentioned.

By making any designation of or reference to a particular territory or geographic area, or by using the term "country" in this document, $A D B$ does not intend to make any judgments as to the legal or other status of any territory or area.

This work is available under the Creative Commons Attribution 3.0 IGO license (CC BY 3.0 IGO)

https://creativecommons.org/licenses/by/3.0/igo/. By using the content of this publication, you agree to be bound by the terms of this license. For attribution, translations, adaptations, and permissions, please read the provisions and terms of use at https://www.adb.org/terms-use\#openaccess.

This CC license does not apply to non-ADB copyright materials in this publication. If the material is attributed to another source, please contact the copyright owner or publisher of that source for permission to reproduce it. $\mathrm{ADB}$ cannot be held liable for any claims that arise as a result of your use of the material.

Please contact pubsmarketing@adb.org if you have questions or comments with respect to content, or if you wish to obtain copyright permission for your intended use that does not fall within these terms, or for permission to use the ADB logo.

Corrigenda to ADB publications may be found at http://www.adb.org/publications/corrigenda.

Note:

In this publication, “\$” refers to United States dollars.

The ADB Economics Working Paper Series presents data, information, and/or findings from ongoing research and studies to encourage exchange of ideas and to elicit comment and feedback about development issues in Asia and the Pacific. Since papers in this series are intended for quick and easy dissemination, the content may or may not be fully edited and may later be modified for final publication. 


\section{CONTENTS}

TABLES AND FIGURES

ABSTRACT $v$ V

$\begin{array}{ll}\text { I. INTRODUCTION } & 1\end{array}$

II. THE POLICY REFORM: THE ROLL-ON ROLL-OFF TERMINAL SYSTEM 2

III. RELATED LITERATURE

IV. METHODOLOGY 6

A. $\quad$ Evaluating the Trade Effects of the Roll-On Roll-Off Terminal System 7

B. Provincial Border Effects 8

V. DATA SOURCES $\quad 8$

A. Starting Dates of Roll-On Roll-Off Services 8

B. Provincial Trade Data 9

C. Production and Consumption 12

D. Prices 13

E. $\quad$ Distance and Language 13

VI. RESULTS $\quad 15$

A. Evaluating the Trade Effects of the Roll-On Roll-Off Terminal System 15

B. Domestic Border Effects 16

VII. CONCLUSIONS AND POLICY IMPLICATIONS 26

$\begin{array}{lr}\text { REFERENCES } & 29\end{array}$ 


\section{TABLES AND FIGURES}

\section{TABLES}

$1 \quad$ Average Inter and Intraprovincial Trade by Product

2 Roll-On Roll-Off Terminal System and Interprovincial Maritime Trade

3 Roll-On Roll-Off Terminal System Spillover Effects

5 Roll-On Roll-Off Terminal System and Province Borders

\section{FIGURES}

1 Provincial Map of the Philippines and the Roll-On Roll-Off Terminal System

2 Number of Port-to-Port Roll-On Roll-Off Terminal System Linkages over Time

4 Total Monthly Frequency of Trade, Roll-On Roll-Off Terminal System versus Non-Roll-On Roll-Off Terminal System Ports

$5 \quad$ Inter and Intraprovincial Trade in Agriculture

7 Reduction of Border Effects from Roll-On Roll-Off Terminal System by Product

9 Reduction of Border Effects from Roll-On Roll-Off Terminal System over Time 


\begin{abstract}
We create two novel datasets-the starting dates of Roll-On Roll-Off Terminal System (RRTS) service by route, and interprovincial land trade - to evaluate the effects of the RRTS on agricultural trade costs within the Philippines as measured by border effects. We find province border effects to be substantial in the Philippines, with a typical province trading 28-53 times more with itself than with other provinces. The RRTS reduced this by a factor of 0.65 . This is confirmed by increased trade flows, with RRTS province pairs trading $36 \%-42 \%$ more on average compared to similar unconnected province pairs. However, the border effect reduction is unevenly distributed and tends to be limited to provinces near the biggest demand center.
\end{abstract}

Keywords: border effects, domestic trade, trade costs

JEL codes: F14, O18, Q10 


\section{INTRODUCTION}

The Government of the Philippines instituted the Roll-On Roll-Off Terminal System (RRTS) in January 2003 with the aim of bringing down interisland domestic trade costs by integrating roll-on rolloff (RORO) shipping routes with land-based national highway networks. RORO vessels facilitate a seamless interface between land and sea transport by foregoing cargo handling procedures.

In this paper, we study the effects of the RRTS on maritime trade of agricultural products and domestic trade costs, as measured by border effects, in the Philippines.

The Philippines provides an interesting setting for studying domestic trade costs. It is an archipelago and faces considerable challenges in integrating the economies of its 7,000 islands. The domestic shipping industry plays a crucial role in the economy, especially for the smaller islands where maritime transport is the only viable means of sustained trade. In 2017, the total value of domestic maritime trade was recorded at $\$ 765$ billion ( $\$ 15.3$ billion), corresponding to 23 million metric tons of goods. ${ }^{1}$

We focus on agricultural products for which trade, production, and consumption data are available. The estimation of province border effects requires these information by location. The agricultural focus is motivated by its role as the main source of livelihood for the poorest provinces, and the sensitivity of agricultural products to trade costs because of their sensitive shelf lives and lower value-to-weight ratio. In 2017, close to 7 million metric tons of agricultural products were transported by sea, comprising $30 \%$ of recorded volume of waterborne trade (PSA 2017a). Finally, the RRTS cites agricultural market linkage and food security as one of its goals.

However, domestic shipping is notoriously expensive. Freight cost per nautical mile from Davao, a major port in the south of the Philippines, to Manila, the capital in the north, on a 20-foot container equivalent (TEU) was estimated to be $\$ 1.50$ in early 2000 , whereas those from Hong Kong, China or Bangkok are at most $\$ 0.50$ (Basilio 2008). In 2010, transporting a TEU from Manila to Cagayan de Oro, a major city in the south, was over $100 \%$ more expensive than moving the same consignment via transshipment through Kaoshung in Taipei,China (Llanto and Navarro 2014).

Against this backdrop, we investigate the impact of the RRTS on domestic agricultural trade on two fronts. First, the effect of RRTS on interprovincial agricultural trade flows is examined. This treats RRTS as a trade cost shifter that is available to some province pairs but not others. Second, provincial border effects as a metric of trade cost are obtained, and RRTS-associated changes to these are mapped across provinces, product, and time. We find that province pairs that have access to the RRTS increased trade by an average of $36 \%$ compared to similar provinces without the connection. The RRTS also reduced province border frictions by 36 percentage points, equivalent to a factor of 0.65 , although it is the provinces nearest the National Capital Region (NCR) that experienced the largest reductions.

To the best of our knowledge, this is the first study that empirically estimates the impacts of the RRTS on trade costs. The empirical exercises required the creation of a historical database that tracks the development of RORO service by route over time; and the recovery of intraprovincial agricultural trade and interprovincial land trade. These datasets form part of our contribution to the literature.

1 The currency exchange rate applied was $\$ 1=\$ 50.43$ as of 23 March 2018 (Bangko Sentral ng Pilipinas 2018). 
The next section lays out the context of the RRTS and explains how it is expected to affect domestic trade costs. Section III reviews the relevant literature. Section IV discusses the methodology. Section $V$ documents the data sources and how the information of RORO service and intraprovincial trade were obtained. Section VI analyzes the results. Finally, section VII concludes.

\section{THE POLICY REFORM: THE ROLL-ON ROLL-OFF TERMINAL SYSTEM}

The RRTS was launched in 2003 through Executive Order 170. The transport network has three main trunks which are called nautical highways: the Pan Philippine Highway, which forms the eastern trunk have RORO operations that predate the RRTS; the western highway started operating as part of the RRTS in 2003; and the central highway became fully operational in 2008. Figure 1 presents the main vertical trunks of the RRTS. The orange lines indicate the main land highways, while the blue lines represent sea routes linked by the RRTS.

RORO facilitates a seamless interface between land and sea transport by dispensing with cargo handling procedures. Referring to Figure 1, a truck coming from Manila can load into a RORO ship in Batangas City and reach Calapan, Mindoro without stopping to load and unload cargoes. This is expected to result to time and monetary savings. Risks of spoilage and pilferage also become lower. Finally, substantial savings also come from inventory management as RORO enables direct delivery of goods to institutional buyers without warehousing.

Other primary means of sea transport are liners and trampers. The former are large vessels that cater to long-haul routes, while trampers can be any kind of ship that are hired by contract to transport bulky commodities (Austria 2002). Finally, there are specialized tanker vessels that carry particular products such as cement, chemicals, and fuels.

Another advantage of the RRTS is that it implicitly addresses cost issues arising from the lack of scale in many provinces in the Philippines. The smallest container ships have a capacity of 250 TEUs, whereas a typical RORO vessel has a capacity of about $60 \%$ of this (Faustino and Morales 2010). The smaller size means RORO ships can make more frequent trips and faster turnarounds. Shipping in smaller batches with higher frequency reinforces savings in warehousing and other logistics-related costs.

The reforms of Executive Order 170 can be classified into two groups. The first refer to those that directly affect shipping cost itself. These include the waiving of cargo handling charges and wharfage dues; freight charging based on lane meter; ${ }^{2}$ and simplified documentary requirements. The second group promotes investments in RORO ports and vessels such as the replacement of port authorities' share in port revenues with registration fees, participation of private ports in the RRTS, and financing from the Development Bank of the Philippines for port development and vessel purchase.

We focus on the first group of reforms, which are expected to have immediate effects on monetary and inventory costs associated with shipping, and time savings from the simplification of procedures. Time savings and schedule flexibility are important for products with sensitive shelf lives. The second set of reforms are expected to reduce shipping cost in the longer run.

2 Freight is levied based on the space occupied by the cargo and the distance that the vessel traveled. 
Figure 1: Provincial Map of the Philippines and the Roll-On Roll-Off Terminal System

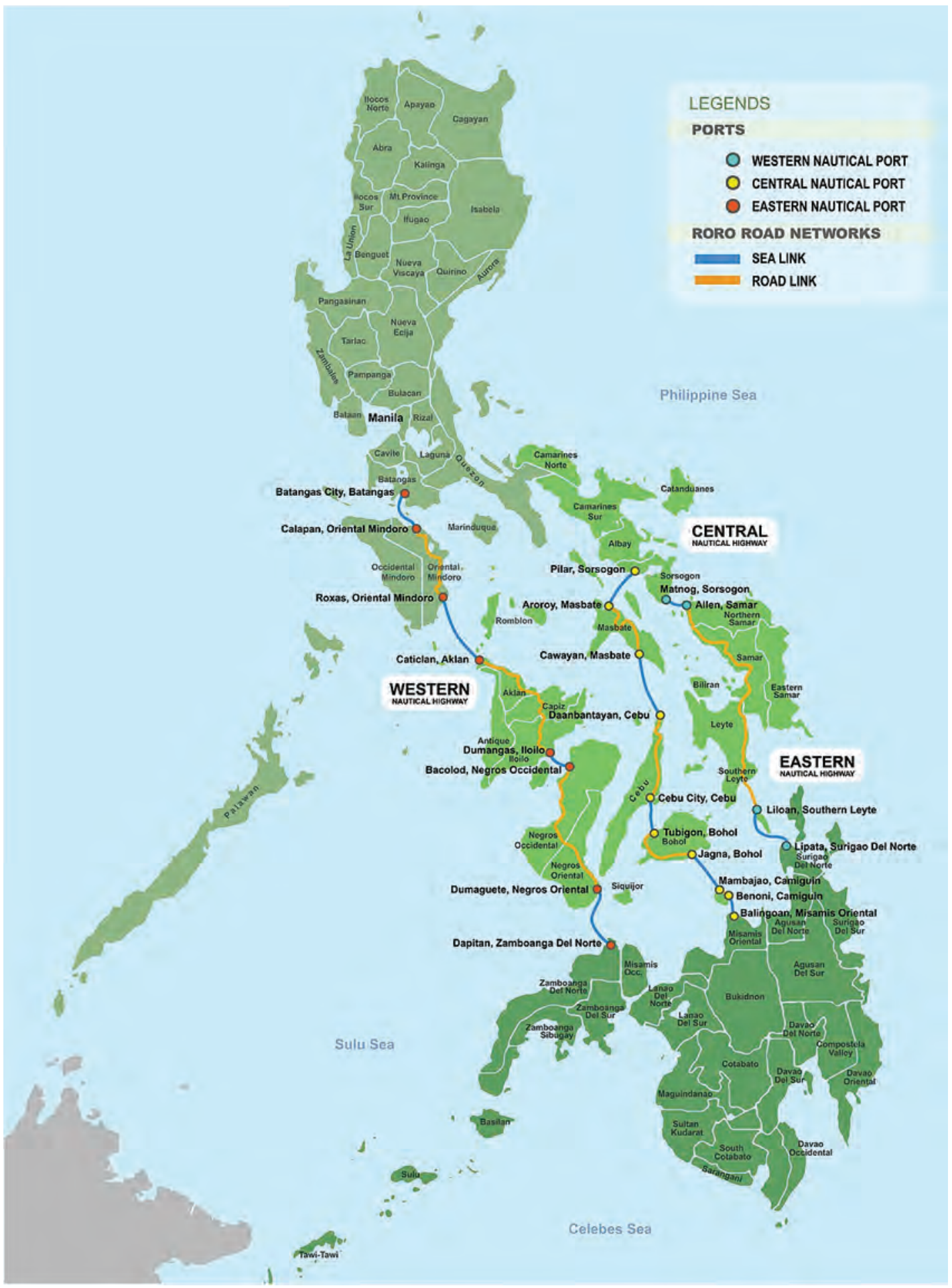

RORO $=$ Roll-On Roll-Off.

Source: Author. 
It is important to distinguish between RORO, which is a vessel type, and the RRTS which is a transport system. Some RORO ships do not function within the RRTS. For example, liner companies sometimes use RORO in lieu of cranes to load containers (mounted on chassis) onto ships. But these still need to be unloaded by a truck head at the port of destination.

There were RORO ships operating before the RRTS. Nonetheless, RORO as a mode of transport did not enjoy a broad take-up. Government controls and bureaucratic delays, as well as irrational cargo handling policies discouraged the use of RORO. For example, truck "clearances" were required for interisland movement as if a cargo was moving from one country to another (USAID 1994). There was also a conflict of interest between the Philippine Ports Authority (PPA) and the deployment of RORO (Llanto, Basilio, and Basilio 2005). The PPA revenue generating structure was biased toward cargo handling operations with handling fees from domestic cargoes accounting for $18 \%$ of the total revenues from port operations in 2001.

Various reports cite positive impacts of the RRTS in terms of passenger and cargo traffic, with growths as high as 300\% and 500\%, respectively, between 2003 and 2006, and reduction in cargo transport costs of as much as 20\%-68\% over a range of routes and products (Basilio 2008; Llanto, Basilio, and Basilio 2005; ADB 2010). The RRTS was thought to be such a success that the Philippines, together with Indonesia were designated to lead the implementation of the Association of Southeast Asian Nations (ASEAN) RORO (Faustino and Morales 2010). The first RORO servicing DavaoGeneral Santos City in the Philippines and Bitung in Indonesia commenced in April 2017. Nonetheless, the effects of RRTS on domestic trade flows and trade costs have yet to be empirically established.

\section{RELATED LITERATURE}

Trade costs comprise of all the resources required to bring one product from production to the final consumer (Anderson and Van Wincoop 2004). They include costs arising from transport and storage, administrative requirements, distribution and markup, exchange rates; and costs imposed exogenously such as distance and culture. Trade cost measures are generally grouped into three categories: (i) direct measures, (ii) estimates from spatial price differences, and (iii) indirect measures from trade flows.

Direct measures of trade costs are sparse. In international trade, tariffs and nontariff barriers are typically used as indicators of policy barriers. Shipping and freight costs are ideal measures of transport costs, but are rarely available except in some developed countries. It has been common for studies to resort to matched partner cost, insurance, freight-free-on-board (cif-fob) ratios as proxy for transport costs. But highly detailed national data from the United States (US) and New Zealand reveal the ratios to be error ridden, with little information that can be exploited for analyzing variations across time or commodities (Hummels and Lugovskyy 2006).

Infrastructure and institutional indicators are considered as direct cost measures in some studies. They are usually proxied for by road networks, telephone density, ease of doing business and logistics performance indicators. However, outside of administrative records, these metrics are mostly derived from perception-based surveys with a select sample of respondents.

A second approach infers trade costs from spatial price gaps. Agricultural products are ideal for such studies because they are produced over extensive geographies and are expensive to transport 
(Fackler and Goodwin 2001). In particular, the macro strand which focuses on retail prices, their transmission, and speed of price adjustment are typically taken to be indicative of trade costs.

Atkin and Donaldson (2019) take the price gap analysis further using a dataset of highly disaggregated products, combined with production location and trade data. They demonstrate that in an oligopolistic setting, pass-throughs of price shocks capture the response of markups to changes in trade costs. They find that the effect of distance on trade costs within Ethiopia and Nigeria are higher by four to five times than within the US.

In light of the practical difficulties in obtaining direct measures and the data demands in the price gap approach, trade cost inference from trade volume is often the remaining option. Gravity models are widely employed to analyze how observable components of trade costs influence trade flows. Arvis et al. (2016) and Jacks, Meissner, and Novy (2008) use this property in an inverse gravity model that expresses trade cost as the ratio of the internal trade of a bilateral pair, and their trade flows with each other. The estimated ad valorem equivalents of trade costs capture both direct costs such as shipping, and indirect costs such as time delays. Nonetheless, the resulting estimates do not give much information for policy makers on trade frictions that affect bilateral trade patterns.

Intranational trade supposedly face less substantial trade frictions than international trade. There are less costs imposed by policies through tariffs and exchange rates. Cultural differences are also expected to play less prominent roles than in the international setting. Indeed, while the size of estimates varies, studies consistently find strong bias toward domestic trade (Havranek and Irsova 2017; Hillberry and Hummels 2003).

Home bias is estimated as an international border effect in the pioneering work of McCallum (1995) who found that Canadian provinces trade 22 times more among themselves than with the US. A recent meta-analysis by Havranek and Irsova (2017) confirms that international border effects remain sizable and tend to be larger for emerging countries.

Border effects have also been derived for trade in services. Anderson et al. (2018) estimate border effects for 28 countries in 12 service sectors. The authors project disaggregated services output data within countries, which is often missing for the service sector. This information enabled distinction between cost that vary within a country and those that vary when a country trades with another.

Home bias has also been observed in the way regions trade within a country and is termed domestic border effect. This is a smaller parallel set of literature to the international counterpart. Interest on domestic border effects started with Wolf (2000) who finds that individual states of the US trade more with themselves than with other states.

More recently, Agnosteva, Anderson, and Yotov (2015) estimate regional border effects using interregional and intraregional trade flows in Canada and find these to vary widely with a tendency of border effects to be larger for smaller regions.

Studies that bring domestic and international border effects into a unified framework provide richer insights by allowing for different levels of comparison. For instance, Anderson and Yotov (2010) find that provincial border effects in Canada are larger than the overall international border effect. Coughlin and Novy (2013) observe a similar pattern in the US, and Fally, Paillacar, and Terra (2010) in Brazil. 
The large magnitude of domestic and international border effects is one of six major puzzles of international macroeconomics (Eaton, Kortum, and Neiman 2015). Nonetheless, the latest developments in gravity estimation has attenuated the border puzzle by about one-third. In particular, the inclusion of zero flows, controlling for multilateral resistance, and consistent measurement of internal and external distance, lead to lower border estimates (Havranek and Irsova 2017).

\section{METHODOLOGY}

Gravity models provide a framework for linking trade flows with observable and unobservable trade cost variables. We use the model as the basis for evaluating the RRTS impact on trade flows and to estimate province border effects. We adopt the structural gravity systems of equation from Anderson and Van Wincoop (2004):

$$
\begin{gathered}
X_{i j}^{k}=\frac{E_{j}^{k} Y_{i}^{k}}{Y^{k}}\left(\frac{\tau_{i j}^{k}}{P_{j}^{k} \pi_{i}^{k}}\right)^{1-\sigma^{k}} \\
\left(\pi_{i}^{k}\right)^{1-\sigma^{k}}=\sum_{j}\left(\frac{\tau_{i j}^{k}}{P_{j}^{k}}\right)^{1-\sigma_{k}} \frac{E_{j}^{k}}{Y^{k}} \\
\left(P_{j}^{k}\right)^{1-\sigma_{k}}=\sum_{i}\left(\frac{\tau_{i j}^{k}}{\pi_{i}^{k}}\right)^{1-\sigma^{k}} \frac{Y_{i}^{k}}{Y^{k}}
\end{gathered}
$$

where $X_{i j}^{k}$ is the export of province $i$ to province $j$ of product $k$; $E_{j}^{k}$ is the expenditure of province $j$ on product $k$; $Y_{i}^{k}$ is the provincial output of $i$ for $k$, and $Y^{k}$ is the total output of all provinces of $k$; $\tau_{i j}$ represents a host of trade barriers between $i$ and $j$, which can also vary by $k$; $P_{j}^{k}$ and $\pi_{i}^{k}$ are the inward and outward multilateral resistance terms, which summarize trade frictions between a province and all its trading partners. Finally, $\sigma$ is the trade elasticity of substitution for product $k$ across origin provinces.

A few notes are in order in using the gravity model:

(i) Equations (1)-(3) imply a relative interpretation of trade costs. A change in trade costs between a province pair induces shifts in trade flows of province $i$ with other trading partners. At the same time, a change in trade costs within a province, $\tau_{i i}$, also influences $\tau_{i j}$. Supposing $i$ to be a province, the decline in trade cost due to the RRTS should tilt trade toward interprovincial trade and away from intraprovince trade, thereby attenuating home bias.

(ii) Gravity assumes the separability of trade flows, and production and consumption decisions within trading units. This implies the Armington assumption of product differentiation by source holds as captured by $\sigma$ in gravity equations. This presents a challenge in an intranational agricultural trade context. Nonetheless, the Armington assumption is still valid if demand is characterized by monopolistic competition and free entry; or supply is akin to a multiple producer homogeneous goods model (Eaton and Kortum (2002). In the latter case, $1-\sigma$ can be interpreted as embodying comparative advantage with a Frechet distribution (Anderson and Yotov 2010). 
(iii) Aggregation methods introduce biases even though the direction of the bias remains unclear (Anderson and Van Wincoop 2004). Bias stemming from product aggregation is not a major concern in our case given that estimation is conducted at the 4-digit Harmonized System code. However, aggregation bias also occurs spatially. Building symmetric micro regions in the US and systematically aggregating these into macro regions, Coughlin and Novy (2016) demonstrate that spatial aggregation influences the size of border estimates. Large states tend to exhibit lower border effects because spatial expansiveness makes it relatively more expensive to trade within states-what the authors call "spatial attenuation effect." To the extent that we cannot address spatial attenuation due to lack of subprovince intratrade data, the implications in the interpretation of border effects are taken on board. However, our estimation of border effects is not done for its own sake. Rather, this is used as an indication of how RRTS affected provincial home bias. In this sense, RRTS is still expected to bring down border effects.

(iv) For many provincial pairs, it is likely that $P_{j}^{k} \neq \pi_{i}^{k}$. Anderson and Yotov (2010) demonstrate that the proportion of trade costs borne by sellers declines over time due to "learning by selling," while that of the buyers' are stable and can even rise. However, we have to abstract from issues of asymmetry because a proper treatment requires a more universal coverage of products.

As is standard in the gravity literature, bilateral trade is assumed to have a Poisson distribution with the conditional mean of observed trade flows following an exponential form. This addresses concerns on heteroscedasticity inherent in the log-linearization process of multiplicative models and allows for a robust estimation in settings where zero flows comprise large shares of the sample (Head and Mayer 2013, Santos Silva and Tenreyro 2006).

\section{A. Evaluating the Trade Effects of the Roll-On Roll-Off Terminal System}

The expected value of trade costs, $\tau_{i j}^{k}$, is modeled as a function of traditional gravity variables and RRTS access in equation (4).

$$
\mathrm{E}\left[\tau_{i j}^{k}\right]=\exp \left[\beta_{1} \operatorname{lnDist}_{i j}+\beta_{2} \operatorname{Lang}_{i j}+\beta_{3} \operatorname{Land}_{i j}+\gamma \operatorname{RRTS}_{i j, t}\right]
$$

$\operatorname{lnDist}_{i j}$ is the log of distance between provinces $i$ and $j . \operatorname{Lang}_{i j}$ is equal to 1 if the majority of the population in a province pair share a common language and 0 otherwise. ${ }^{3}$ Land $_{i j}$ takes a value of 1 if a trade flow occurs by land rather than by sea. Finally, $R R T S_{i j, t}$ is a dummy variable equal to 1 once a province pair is serviced by a RORO ship.

Incorporating $\tau_{i j}$ into the gravity model yields equation (5):

$$
X_{i j, t}^{k}=\exp \left[\beta_{1} \operatorname{lnDist}_{i j}+\beta_{2} \operatorname{Lang}_{i j}+\beta_{3} \operatorname{Land}_{i j}+\gamma R R T S_{i j, t}+\eta_{i, t}+\theta_{j, t}+\delta_{k, t}+\epsilon_{i j, t}^{k}\right]
$$

\footnotetext{
3 Religion could not be included in the specification because a variance inflation factor analysis reveals it to be highly collinear with distance.
} 
where origin-year fixed effects, $\eta_{i, t}$; and destination-year fixed effects, $\theta_{j, t}$ wash out year-to-year changes in origin and destination provinces. $\delta_{k, t}$ controls for changes in demand and supply conditions of products within the country. Finally, $\epsilon_{i j, t}^{k}$ is the error term.

However, the likelihood of province pairs investing in RRTS infrastructure increases with the expected benefits of doing so. The selection issue we confront here is analogous to the identification of the impact of regional trade agreements on bilateral trade flows. Baier and Bergstrand (2007) account for endogeneity of regional trade agreements by introducing pair fixed effects. These are represented by $\alpha_{i j}$ in equation (6), which partial out all nontime-varying characteristics between provincial pairs that influence their propensity to trade with each other, and therefore invest in RRTS connection. Controlling for the changes in demand and supply conditions of products, $\delta_{k, t}$, leaves $\gamma$ to capture the remaining variation coming from provincial RRTS linkage status.

$$
X_{i j, t}^{k}=\exp \left[\alpha_{i j}+\gamma R R T S_{i j, t}+\eta_{i, t}+\theta_{j, t}+\delta_{k, t}+\epsilon_{i j, t}^{k}\right]
$$

\section{B. Provincial Border Effects}

Estimating province border friction requires information on intraprovince and interprovince trade. The former is not readily available and is derived using several data sources. This is detailed in the next section.

The province border effect is obtained by estimating:

$$
X_{i j, t}^{k}=\exp \left[\beta_{1} \operatorname{lnDist}_{i j}+\beta_{2} \operatorname{Lang}_{i j}+\beta_{3} \operatorname{Land}_{i j}+\psi \operatorname{Smprov}_{i j}+\eta_{i, t}+\theta_{j, t}+\delta_{k, t}+\epsilon_{i j, t}^{k}\right]
$$

$\operatorname{Smprov}_{i j}$ is a binary variable equal to 1 when trade is within the province, $i=j$; and 0 if it is interprovincial trade, $i \neq j$. If interprovince trade were frictionless, $\hat{\psi}$ should not be statistically different from zero. Smprov is first estimated off a homogeneity assumption and is then later varied across the dimensions of product, provinces, and time.

\section{DATA SOURCES}

\section{A. Starting Dates of Roll-On Roll-Off Services}

We create a historical database of RORO services using information from various sources and this dataset forms a key component of our work's contribution.

(i) The Maritime Industry Authority (MARINA) inventory of RORO routes indicates that there were 39 shipping companies servicing around 150 distinct routes as of 2017. These companies were requested to provide the starting date of their operations for each route. Twenty companies responded to the request.

(ii) We access the certificates of public convenience of 10 shipping companies registered with the MARINA central and Region IV offices. The certificates of public convenience specify the route and schedule franchise of a shipping company. These records are physically distributed across the 13 MARINA regional offices in the Philippines. 
(iii) The information obtained from the first item and second item in this list were verified against the information provided by the PPA on the location and availability of RORO ports by date.

(iv) Some reports and feasibility studies of institutions and international aid agencies have information on starting dates of RORO services for some routes: ADB (2010); JICA (1992, 2007); accomplishment reports of the PPA; and USAID (1994, 2014). Local news articles were also used to verify and complete the database. Less formally, we also use information from the Philippine Ship Spotters Society.

(v) Finally, the information from different sources were mapped with each other. Among the sources, only the Philippine Statistical Authority (PSA) employs a universal port classification system that directly links a port of origin and destination to trade flows. Substantial effort was expended in ensuring geographical concordance.

Figure 2 shows that the number of RRTS linked port pairs increased rapidly from less than 40 at the start of the program to 113 in 2014.

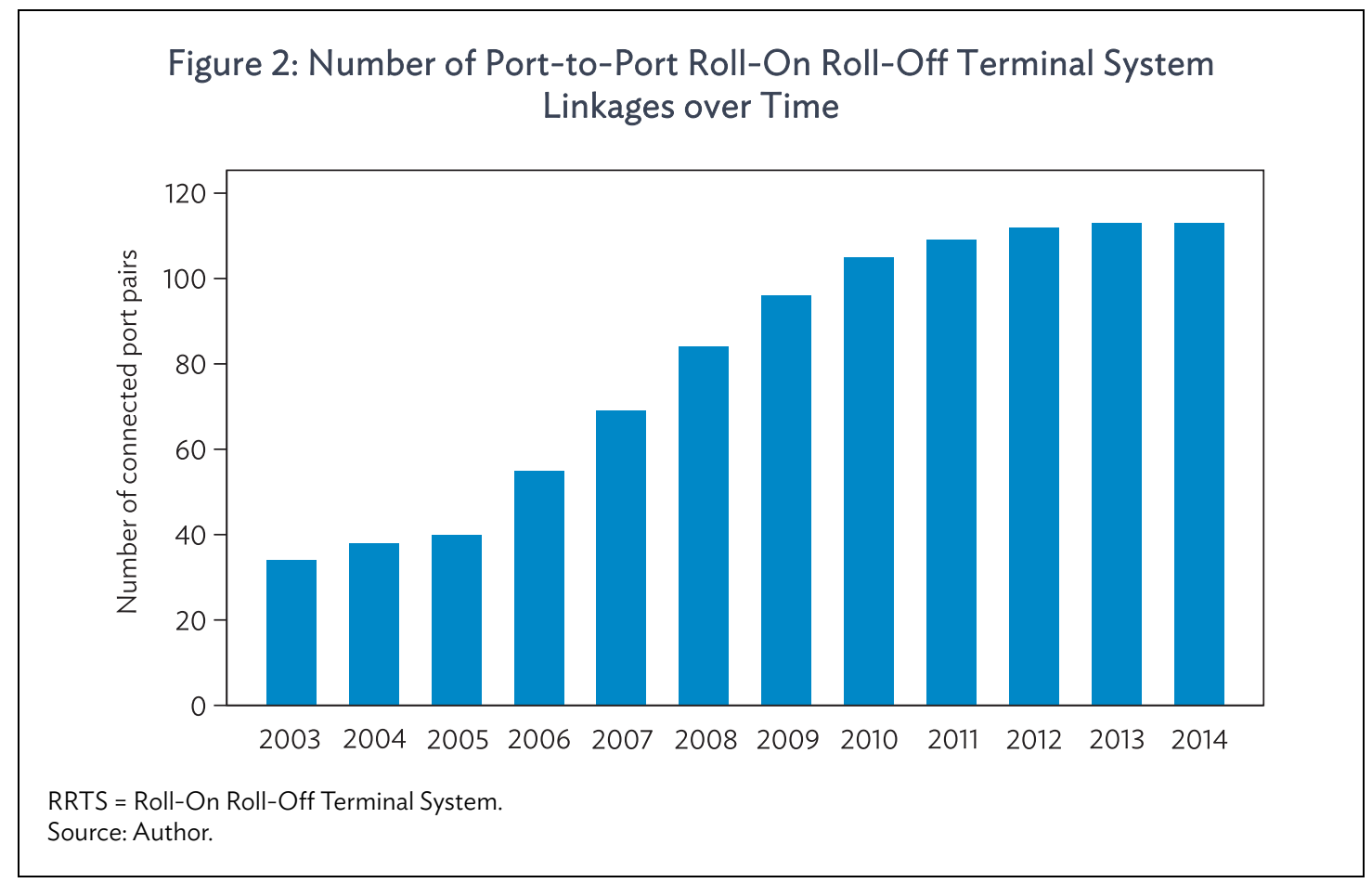

\section{B. Provincial Trade Data}

Maritime trade by origin and destination. The PSA records monthly volume and value flows of maritime trade by port of origin and destination at the 5-digit Philippine Standard Commodity Classification.

However, the geographic configuration of the Philippines means that maritime trade data cannot give a comprehensive picture of provincial trade. Some provinces are largely islands in 
themselves such as Bohol and Palawan, while others are contiguous by land such as those that make up most of Luzon and Mindanao.

Interprovince land trade. The PSA does not track commodities transported by land, and yet this is a key component of the information for estimating province borders. Without this, derived intraprovince trade will be overestimated because exports by land will be unaccounted for. We remedy this by using Marketing Cost Structure Studies from the Bureau of Agricultural Statistics to retrieve trade flows by land. These studies identify the main supply and destination provinces for certain commodities for selected years. The amount available for export is capped at the difference between production and consumption of a supply province. A summary of the geographic flow for each commodity is described in Table A. 1 in the online Appendix. ${ }^{4}$

Intraprovincial trade. Intraprovincial trade is derived as follows:

$$
X_{i i}^{k}=\left\{\begin{array}{lc}
\operatorname{Prod}_{i}^{k} x A^{k}-\sum_{i \neq j} X_{i j,}^{k} & \text { if } X_{i i}^{k}>0 \\
\operatorname{Prod}_{i}^{k} x A^{k}, & \text { Otherwise }
\end{array}\right.
$$

$X_{i j, t}^{k}$ refers to exports of $i$ to other provinces and international markets $j$ of product $k$ for year $t$. $X_{i j, t}^{k}$ also includes processed forms of bananas, mangoes, and pineapples, which are exported in substantial volumes to international markets. For purposes of tractability, a one-to-one correspondence is used. For example, a kilo of fresh pineapple is assumed to be equivalent to one kilo of canned pineapple. This is clearly not the case. However, international trade data is in units of gross kilograms and include the weight of packaging and other additives. Information on international exports by province are sourced from the PSA and were converted to their peso equivalent using the average monthly exchange rates from the Bangko Sentral ng Pilipinas (2016).

$A^{k}$ is an adjustment factor sourced from the PSA (2017b). This accounts for the proportion of $k$ that are processed, and those that are used as seeds, feeds and waste.

Transshipment. The issue of transshipment is known as the Rotterdam effect in the international trade literature and is a frequent feature of trade data. The products in our dataset are mostly produced and consumed in the Philippines. Products with the highest share of imports in domestic consumption are chicken (12.5\%) and pork (10.7\%) (PSA 2016). Hence, international transshipment is not a prominent concern.

Nonetheless, transshipment remains a potential issue in domestic trade. The PSA trade data are sourced from the outward coasting manifests and do not identify the final destinations of shipments. In the context of RRTS in Figure 1, this means that a delivery truck from the port of Batangas, which passes through Mindoro may actually be destined for Aklan. Mindoro will appear as if it is increasing its exports to Aklan whereas it is actually Batangas that is shipping to Aklan.

There is no systematic way by which we can correct this. But several points mitigate the concern. First, cargo trucks tend to use only one or two chains in the RRTS (JICA 2007). For example, in the Batangas to Aklan route comprising of two RRTS links, $80 \%$ of those departing from Batangas are destined for Mindoro, and only $20 \%$ are moving further on to Aklan. Second, RRTS loses its advantage

4 The Appendix tables referred to in this paper can be accessed online at https://www.adb.org/publications/over-land-oversea-trade-frictions-philippines. 
vis-á-vis liner shipping as distance increases. A JICA (2007) report estimated the threshold to be around 200 kilometers $(\mathrm{km})$. The fact that boarding of RORO ships is on a first-come first-served basis complicates the coordination process, as the number of links to cross increases.

Even outside of the RRTS, transshipment can be an issue. This is most easily appreciated in the case of the NCR, which does not produce commercial quantities of agricultural products and yet serves as an import and export hub to other provinces. We overcome this by mapping NCR exports to their origin provinces using the Marketing Cost Structure Studies as described and summarized in Appendix Table A.2.

Figure 3 presents agricultural maritime trade trends between province pairs by RRTS connection status. In general, trade value between RRTS province pairs is growing faster. The short dashed line that pertains to pairs that become connected with RRTS, regardless of the period of connection, confirms that this is not an artefact of the increasing number of connections.

Figure 3: Agricultural Trade by Roll-On Roll-Off Terminal System Status
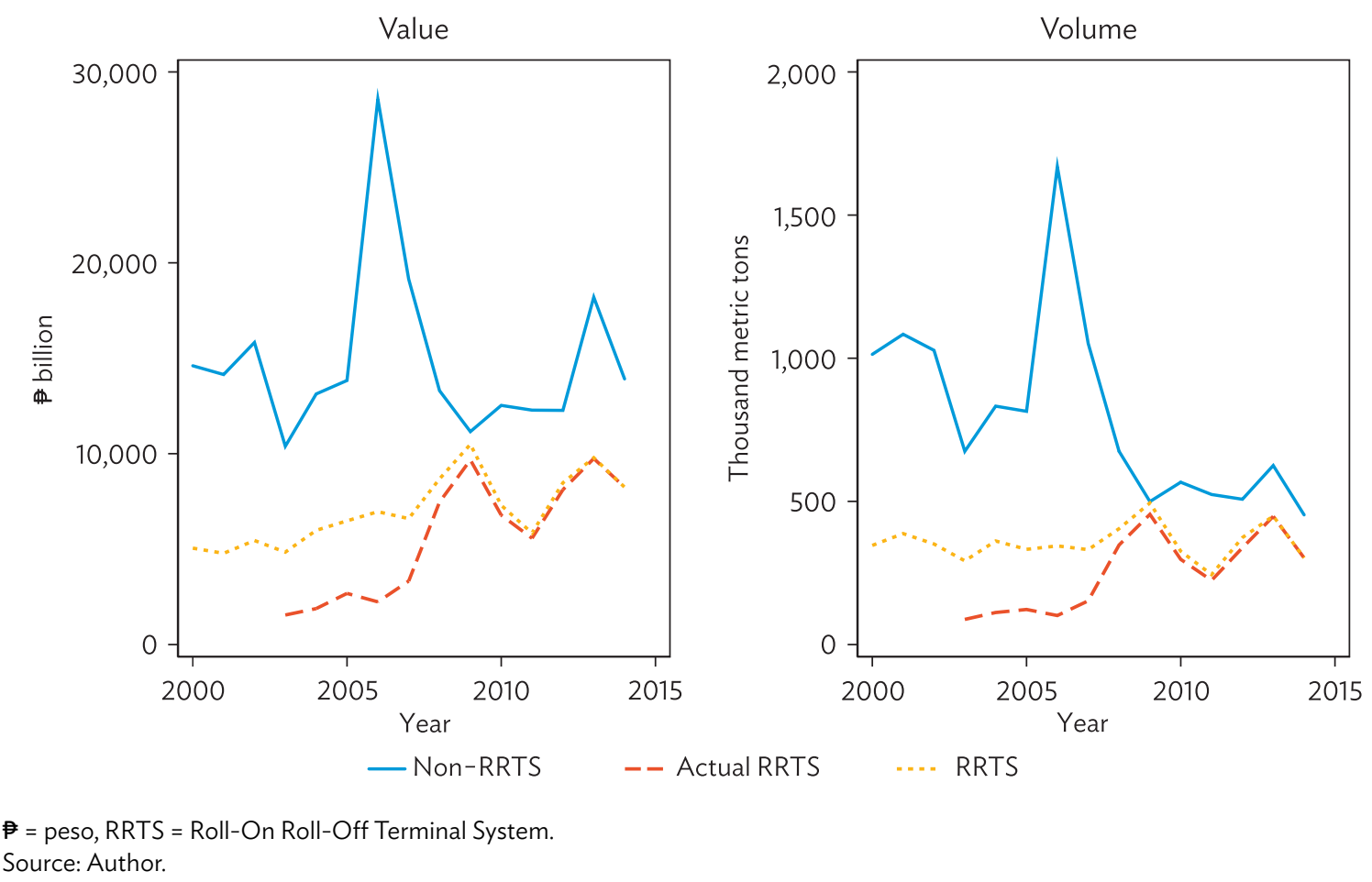

Source: Author. 
Figure 4: Total Monthly Frequency of Trade, Roll-On Roll-Off Terminal System versus Non-Roll-On Roll-Off Terminal System Ports

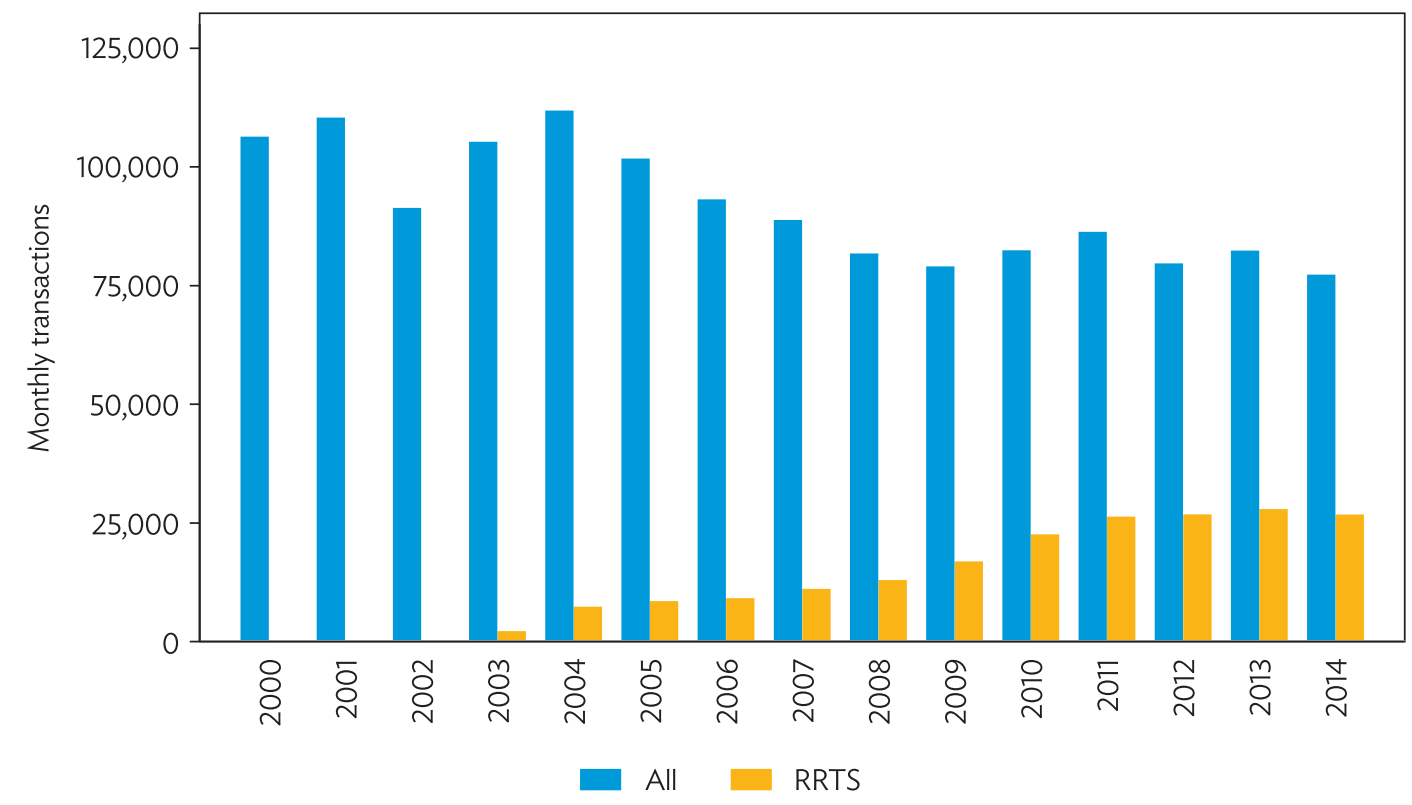

RRTS $=$ Roll-On Roll-Off Terminal System .

Source: Author.

However, this pattern is not observed for trade volumes, which appear to have been stable throughout the period. At the same time, provinces linked by RRTS have higher transaction frequencies even as the total frequencies for the 14 agricultural products are declining (Figure 4).

\section{Production and Consumption}

The PSA assembles production data of major crops and animals at the provincial level. Missing information were imputed using the regional production trend. Adjustment factors from the PSA (2016) were used to match production with consumption and trade data. For example, production data is in terms of paddy, whereas trade is in both rice and paddy, and consumption is in terms of rice. Details of the adjustment factors are in Appendix Table A.3.

Annual provincial consumption was derived using the per capita consumption for 2008 and 2012, multiplied by the provincial population estimates from the PSA (2000) and the resulting projections for the intercensal years. ${ }^{5}$

5 Consumption patterns are assumed to change slowly, and hence, not surveyed regularly. Consumption estimates are available for 1999. However, a change in sampling methodology implemented between 1999 and 2008 renders the series incomparable across time. 


\section{Prices}

The value equivalent of intraprovincial trade and land-based interprovincial flows were derived using annual provincial wholesale prices by product from the PSA. Gaps in price observations were imputed using the following sources in order of priority: (i) provincial retail price trends, (ii) regional wholesale price trends, and (iii) regional retail price trends. Appendix Table A.4 shows the mapping of consumption, production, price, and trade datasets.

\section{E. Distance and Language}

Geodesic distance between provincial trading pairs were derived from geographical coordinates in DIVA-GIS. ${ }^{6}$ The PSA also maintains records of freight revenue along with the exported volume and value. However, we are unable to use them as measures of transport costs because they are not recorded consistently within ports and over time. Moreover, because the data is recorded by month, we cannot be certain that the reported freight revenue corresponds to actual total shipments.

Information on language is obtained from the PSA (2000).

The resulting dataset is a balanced panel of 40,650 observations, covering exports of 60 provinces and the bilateral trade of 822 province pairs over a period of 15 years from 2000 to 2014. Land trade flows comprise $4 \%$ percent of the observations, and intraprovince flows account for $13 \%$. Zeroes comprise $50.9 \%$ of the observations suggesting highly irregular trade flows between provincial pairs across products. Among seaborne interprovincial trade, $32 \%$ of the province pairs became linked by RRTS by 2014.

Figure 5 shows the evolution of interprovincial and intraprovincial agricultural trade. Both are increasing, but intraprovince trade is at least twice as large as interprovince trade and is moreover increasing faster. Table 1 provides a summary of the average annual intraprovince and interprovince trade by commodity. The larger volume and value of intraprovince trade is suggestive of consequential province border effects.

6 DIVA-GIS. Philippines Administrative Areas. DIVA-GIS 7.4. https://www.diva-gis.org/download (accessed 17 September 2016). 
Figure 5: Interprovincial and Intraprovincial Trade in Agriculture
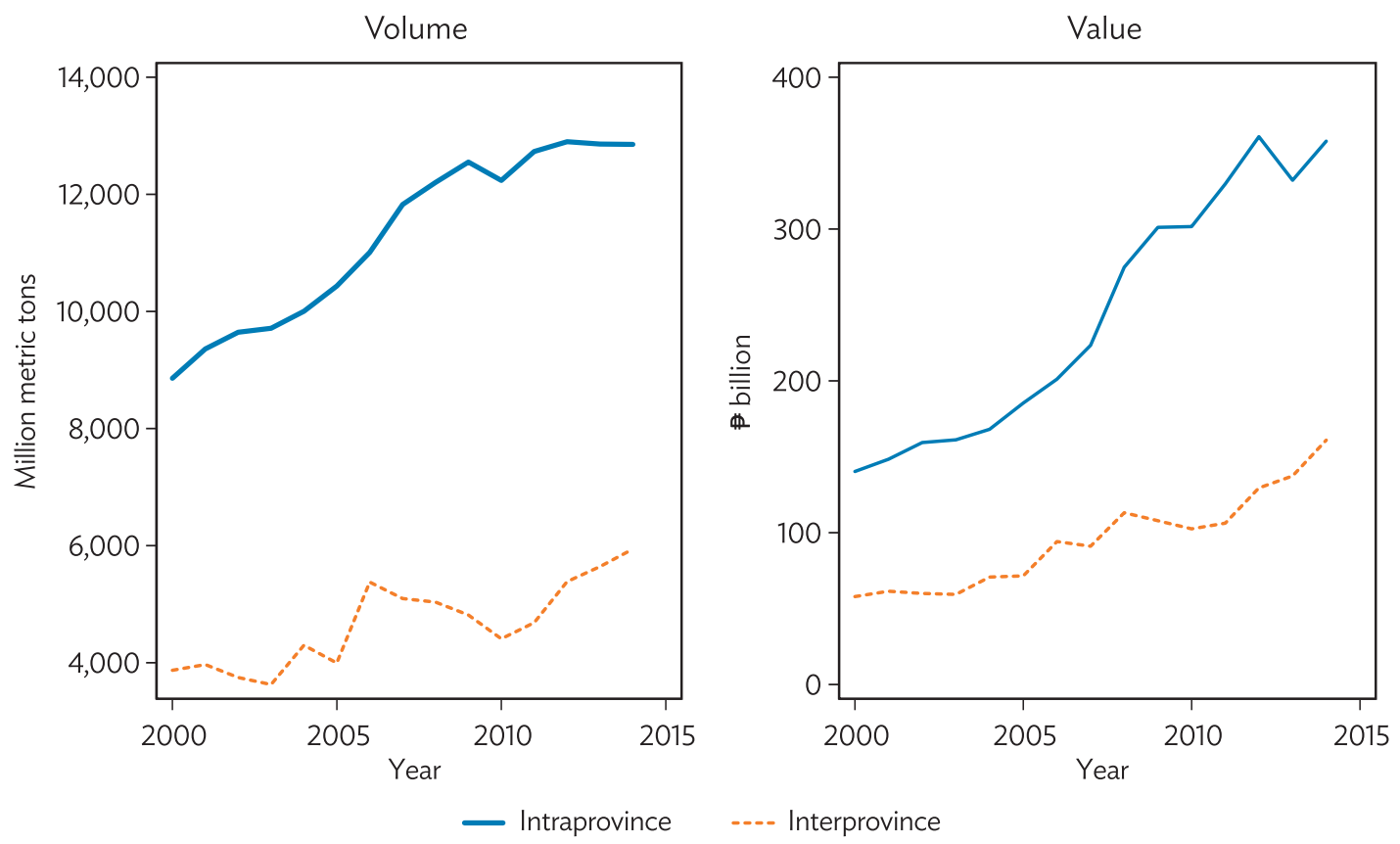

F = peso.

Source: Author.

Table 1: Average Interprovincial and Intraprovincial Trade by Product

\begin{tabular}{|c|c|c|c|c|c|c|}
\hline \multirow[b]{2}{*}{ Product } & \multicolumn{2}{|c|}{ Interprovince } & \multicolumn{2}{|c|}{ Intraprovince } & \multicolumn{2}{|c|}{ Observations } \\
\hline & $\begin{array}{l}\text { Quantity } \\
\text { (MT) }\end{array}$ & $\begin{array}{c}\text { Value } \\
\text { (P billion) }\end{array}$ & $\begin{array}{l}\text { Quantity } \\
\text { (MT) }\end{array}$ & $\begin{array}{c}\text { Value } \\
\text { ( } 尹 \text { billion) }\end{array}$ & $\begin{array}{c}\% \\
\text { Zeroes }\end{array}$ & Total \\
\hline Banana & $2,286.0$ & 36 & $37,620.0$ & 585 & 51.7 & 3,930 \\
\hline Cabbage & 12.6 & 0 & $1,115.0$ & 19 & 57.0 & 1,440 \\
\hline Calamansi & 60.3 & 1 & 269.2 & 6 & 58.9 & 1,920 \\
\hline Carrots & 24.6 & 1 & 608.9 & 20 & 59.6 & 1,605 \\
\hline Cassava & $3,331.0$ & 42 & $5,743.0$ & 77 & 52.0 & 2,250 \\
\hline Chicken & 27.1 & 2 & 785.1 & 50 & 54.5 & 1,920 \\
\hline Corn & $23,160.0$ & 290 & $26,270.0$ & 357 & 44.7 & 4,410 \\
\hline Mango & $5,508.0$ & 167 & $5,433.0$ & 174 & 44.0 & 3,585 \\
\hline Onion & 962.3 & 41 & 535.5 & 25 & 45.8 & 3,285 \\
\hline Pineapple & 136.5 & 3 & $11,860.0$ & 253 & 52.1 & 3,045 \\
\hline Pork & 769.1 & 29 & $4,803.0$ & 328 & 52.6 & 1,545 \\
\hline Potato & 910.4 & 26 & 453.1 & 14 & 56.9 & 1,920 \\
\hline Rice & $35,200.0$ & 851 & $71,610.0$ & 1,671 & 51.3 & 7,590 \\
\hline Tomato & 689.6 & 13 & 638.1 & 13 & 50.1 & 2,415 \\
\hline Total & $113,822.1$ & 1,501 & $126,999.3$ & 3,592 & 50.9 & 40,860 \\
\hline
\end{tabular}

F = peso, MT = metric ton.

Source: Author's calculations. 


\section{RESULTS}

\section{A. Evaluating the Trade Effects of the Roll-On Roll-Off Terminal System}

The effect of the RRTS on trade flows is first estimated with traditional gravity covariates in equation (5). The results in column 1 of Table 2 suggest that the RRTS increased trade in connected provinces by almost $300 \%\left[\left(e^{1.363}-1\right) \times 100 \%\right]$. Among the gravity covariates, only distance is a significant determinant of trade. A $1 \%$ increase in distance reduces trade by $0.43 \%$.

However, these results are subject to endogeneity. Results from the preferred specification with province-pair fixed effects using equation (6) are summarized in column 2. In this set of results, the RRTS coefficient is substantially smaller at 0.31 , implying that RRTS province pairs trade $36 \%$ more compared to similar unlinked pairs. In column 3, origin and destination-year fixed effects are included together with pair fixed effects and this improves the precision of the estimates suggesting a $42 \%$ increase in trade for RRTS pairs. Finally, as a robustness exercise, columns 4-6 present the results for regressions with volume of trade rather than value as a dependent variable, and they confirm the positive effect of RRTS on trade flows.

Table 2: Roll-On Roll-Off Terminal System and Interprovincial Maritime Trade

\begin{tabular}{|c|c|c|c|c|c|c|}
\hline & $\begin{array}{c}(1) \\
\text { Value }\end{array}$ & $\begin{array}{c}(2) \\
\text { Value }\end{array}$ & $\begin{array}{c}(3) \\
\text { Value }\end{array}$ & $\begin{array}{c}\text { (4) } \\
\text { Volume }\end{array}$ & $\begin{array}{c}\text { (5) } \\
\text { Volume }\end{array}$ & $\begin{array}{c}\text { (6) } \\
\text { Volume }\end{array}$ \\
\hline RRTS & $\begin{array}{l}1.363^{* * *} \\
(0.255)\end{array}$ & $\begin{array}{c}0.311^{*} \\
(0.164)\end{array}$ & $\begin{array}{l}0.348^{* * *} \\
(0.120)\end{array}$ & $\begin{array}{l}1.556^{* * *} \\
(0.273)\end{array}$ & $\begin{array}{c}0.351^{*} \\
(0.188)\end{array}$ & $\begin{array}{l}0.437^{* * *} \\
(0.123)\end{array}$ \\
\hline Log distance & $\begin{array}{l}-0.433^{* * *} \\
(0.125)\end{array}$ & & & $\begin{array}{r}-0.086 \\
(0.139)\end{array}$ & & \\
\hline Language & $\begin{array}{r}0.0144 \\
(0.253)\end{array}$ & & & $\begin{array}{c}0.314 \\
(0.246)\end{array}$ & & \\
\hline Observations & 30,300 & 30,300 & 30,300 & 30,300 & 30,300 & 30,300 \\
\hline Origin-year FE & Yes & No & Yes & Yes & No & Yes \\
\hline Destination-year FE & Yes & No & Yes & Yes & No & Yes \\
\hline Product-year FE & Yes & Yes & Yes & Yes & Yes & Yes \\
\hline Pair FE & No & Yes & Yes & No & Yes & Yes \\
\hline
\end{tabular}

$\mathrm{FE}=$ fixed effect.

Notes: Robust standard errors in parentheses clustered at province pairs. ${ }^{* *} p<0.01,{ }^{* *} p<0.05,{ }^{*} p<0.1$.

Source: Author's calculations.

In Table 3, the spillover effects of RRTS to adjacent provinces are examined by introducing a variable, Spill $_{i j, t}$, that is equal to 1 for a non-RRTS province that is trading with an RRTS-linked province. The results from the preferred specification in columns 2 and 3 suggest that effects on trade flows for neighboring non-RRTS provinces are negligible. This confirms that the increase in trade flows between RRTS provinces does not come from displacing trade from unconnected provinces. 
Table 3: Roll-On Roll-Off Terminal System Spillover Effects

\begin{tabular}{lccc}
\hline & $(1)$ & $(2)$ & $(3)$ \\
& Value & Value & Value \\
\hline RRTS & $1.300^{* * *}$ & $0.319^{*}$ & $0.343^{* * *}$ \\
& $(0.334)$ & $(0.187)$ & $(0.118)$ \\
Spillover & $0.933^{* * *}$ & -0.179 & 0.197 \\
& $(0.334)$ & $(0.168)$ & $(0.212)$ \\
Log distance & 0.29 & & \\
Language & $(0.244)$ & & \\
& $0.705^{* *}$ & & 30,300 \\
\hline Observations & $(0.292)$ & & Yes \\
\hline Origin-year FE & 30,300 & 30,300 & Yes \\
Destination-year FE & Yes & No & Yes \\
Product-year FE & Yes & No & Yes \\
Pair FE & Yes & Yes & Yes \\
\hline
\end{tabular}

FE = fixed effect, RRTS = Roll-On Roll-Off Terminal System.

Notes: Robust standard errors in parentheses clustered at province pairs. ${ }^{* *} p<0.01$, ${ }^{* *} p<0.05,{ }^{*} p<0.1$.

Source: Author's calculations.

\section{B. Domestic Border Effects}

Table 4 summarizes the results from equation (7). Intraprovincial flows are excluded in columns 1 and 2 as a baseline comparison. The distance coefficients exhibit the expected signs and magnitudes. The dominant role of trade by land is clearly apparent and reflective of its large share in domestic trade for the big island groups of Luzon and Mindanao.

The negative and significant coefficient on language is not as surprising as it first appears. Provinces that are connected by land are more likely to share a common language, and thereby trade less by sea. The negative effect also disappears when allowing for possible nonlinear effects of distance in column 2. Distance is classified as short if provinces are less than $402 \mathrm{~km}$ apart. This is the distance between Zamboanga del Sur and Tawi-Tawi, which is the second most distant province pair serviced by a RORO ship.7

In columns 3 and 4, we include intraprovince trade but limit the sample to maritime flows. The distance elasticities are in line with expectations. Province border effect as captured by $\hat{\psi}$ is positive and highly significant, although the effect is insignificant in column 4, pointing to possible collinearity due to larger overlaps with the Smprov ${ }_{i j}$ and the short distance indicator in a reduced sample size. Finally, columns 5 and 6 present the results for the full dataset, showing province border effects to be positive and highly significant under both the linear and nonlinear distance set-up.

7 The farthest distance is over $500 \mathrm{~km}$ between the centroids of NCR and Palawan. But this represents a special case since the NCR is only connected to Palawan by RRTS. However, they mainly cater to tourists rather than cargo operations. 
Table 4: Province Border Effects

\begin{tabular}{lllllll}
\hline & $(1)$ & $(2)$ & $(3)$ & $(4)$ & $(5)$ & $(6)$ \\
& Base & Base & Sea & Sea & Full & Full \\
\hline Log distance & $-0.670^{* * *}$ & $-0.782^{* * *}$ & $-0.479^{* * *}$ & $-0.460^{* * *}$ & $-0.406^{* * *}$ & $-0.504^{* * *}$ \\
& $(0.0796)$ & $(0.106)$ & $(0.128)$ & $(0.122)$ & $(0.0826)$ & $(0.0847)$ \\
Language & $-0.599^{* *}$ & -0.298 & 0.292 & 0.261 & 0.199 & 0.278 \\
& $(0.259)$ & $(0.246)$ & $(0.245)$ & $(0.288)$ & $(0.186)$ & $(0.188)$ \\
Land & $3.799^{* * *}$ & $4.185^{* * *}$ & & & $4.370^{* * *}$ & $4.527^{* * *}$ \\
& $(0.222)$ & $(0.280)$ & & & $(0.190)$ & $(0.239)$ \\
Short distance & & -1.121 & & 2.216 & & -1.442 \\
& & $(1.191)$ & & $(1.601)$ & & $(1.157)$ \\
Log distance Short & & 0.0686 & & $-0.484^{*}$ & & 0.201 \\
distance & & $(0.210)$ & & $(0.286)$ & & $(0.205)$ \\
Smprov & & & $3.218^{* * *}$ & 0.904 & $3.329^{* * *}$ & $3.970^{* * *}$ \\
& & & $(0.852)$ & $(1.557)$ & $(0.502)$ & $(1.016)$ \\
\hline Observations & 35,040 & 35,040 & 39,105 & 39,105 & 40,650 & 40,650 \\
\hline
\end{tabular}

Notes: Robust standard errors in parentheses clustered at province pairs. Regressions include origin and destination year, and product-year fixed effects. ${ }^{* *} p<0.01,{ }^{* *} p<0.05,{ }^{*} p<0.1$.

Source: Author's calculations.

The estimated trade friction coefficient ranges from 3.33 to 3.97 . This means that provinces trade 28-53 more times with themselves than with other provinces. These are large effects, but are in the range of estimates in the literature. In a survey by Havranek and Irsova (2017), international border effect estimates for developed countries are around 0.54-2.19, whereas coefficients for emerging countries are around 3.2. The border effects in Table 4 are larger. However, this is not surprising given the archipelagic geography of the Philippines.

Border effects are not to be interpreted as trade cost per se. Rather, they capture the whole range of frictions that prevent trade from freely flowing between provinces. They include transport and storage costs, product characteristics, information and marketing costs, and government policies affecting movement of products such as quarantine regulations.

The impact of RRTS on domestic border effects is estimated by interacting the same province variable with the RRTS indicator, $\operatorname{Smprov}_{i j} \times \operatorname{RRTS}_{i, t}$. For this set of analysis, we exclude landlocked provinces and this reduces the number of provinces in the sample from 60 to 51. The results in Table 5 suggest that the RRTS reduced overall trade frictions by 35-36 percentage points. This supports the earlier set of results that RRTS raised interprovincial maritime trade flows. 
Table 5: Roll-On Roll-Off Terminal System and Province Borders

\begin{tabular}{lcc}
\hline & $(1)$ & $(2)$ \\
& Value & Value \\
\hline Log distance & $-0.396^{* * *}$ & $-0.463^{* * *}$ \\
Short distance & $(0.0889)$ & $(0.0852)$ \\
& & -1.183 \\
Log distance x Short distance & & $(1.485)$ \\
& & 0.173 \\
Language & $0.429^{* * *}$ & $(0.265)$ \\
& $(0.163)$ & $0.483^{* * *}$ \\
Land & $4.553^{* * *}$ & $(0.186)$ \\
& $(0.216)$ & $4.665^{* * *}$ \\
Smprov & $3.926^{* * *}$ & $(0.288)$ \\
& $(0.566)$ & $4.526^{* * *}$ \\
RRTS $\times$ Smprov & $-0.443^{* *}$ & $(1.341)$ \\
& $(0.187)$ & $-0.437^{* *}$ \\
\hline Observations & 36,600 & $(0.184)$ \\
\hline
\end{tabular}

Notes: Robust standard errors in parentheses clustered at province pairs. Regressions include origin and destination year, and product-year fixed effects. ${ }^{* * *} p<0.01,{ }^{* *} p<0.05,{ }^{*} p<0.1$.

Source: Author's calculations.

\section{(1) Varying by Product}

Thus far, equation (8) has been estimated with the assumption of homogeneous border effect. This assumption is now relaxed to let border effects vary by product, time, and provinces. ${ }^{8}$

To estimate border effects by product, $\operatorname{Smprov}_{i j}$ is interacted with product dummies $\delta^{k}$, where $k$ represents each of the 14 products in the observation, that is, $\operatorname{Smprov}_{i j} \times \delta^{k}$. The border coefficient estimates for each product are presented in Figure 6. Estimates for the gravity covariates are in column 1 of Appendix Table A.5. The border effects for all 14 products are positive and statistically significant.

We expect lower value products to have higher border effects because low value-to-weight ratio means that the share of shipping costs in the delivery price is higher. This is part of the story in Figure 6 to a certain extent. But other product characteristics also play an important role in determining tradability.

For example, chicken and pork, despite being of higher value, require refrigeration. Pork is also barely traded in predominantly Muslim provinces. Border effects likewise capture product-specific policies. For instance, pork from Luzon cannot be transported to Mindanao and Visayas without quarantine clearance until 2015, the latter two regions being officially recognized as free from foot and mouth disease (BAI 2015).

8 Nonlinear distance specifications do not work well with product, time, and province varying border effects. Variance inflation factor analysis reveals a high degree of collinearity when nonlinear distance variables are included. 


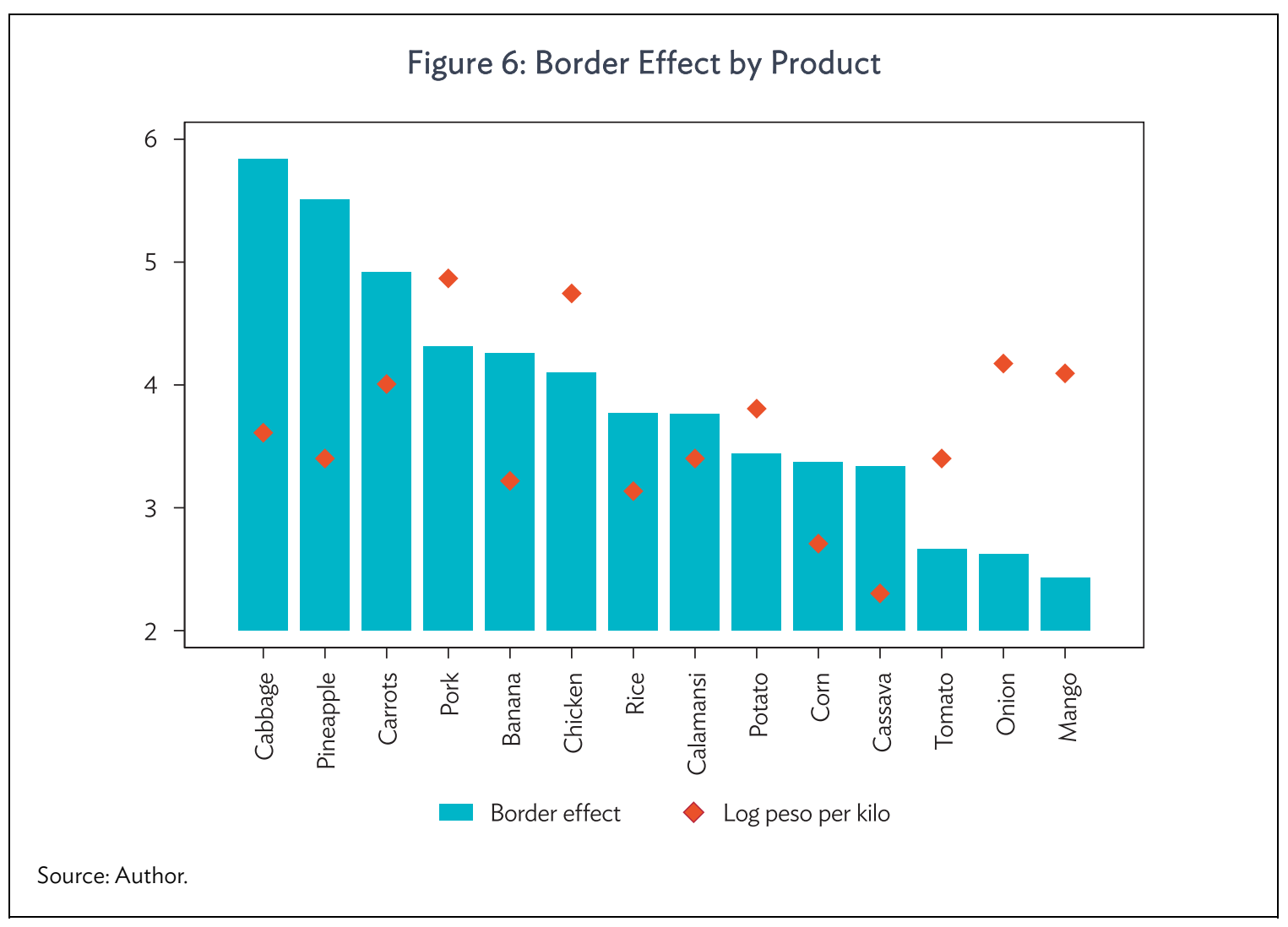

Bananas and pineapples, on the other hand, have postharvest losses averaging above 30\%, and thus also require careful handling because of their high perishability (Andales and Gragasin 2000). Both products are traded internationally in high volumes, and are mostly exported in their processed forms, with processing plants locating near the sources of raw materials. Exporting and processing activities are accounted for in the imputation of intraprovince and land-based trade. Nonetheless, both products also exhibit heterogeneity in terms of the variety exported and those consumed locally. For example, Cavendish bananas are destined for exports, whereas local consumption is more often that of sweet plantains and lacatan, which are of lower value.

Mangoes, onions, and tomatoes have the lowest border effects. These appear to be driven by a mix of higher unit values and geographic specificity in terms of production. For example, tomatoes are grown in Bukidnon, and onions are grown in Nueva Ecija and Pangasinan. Yet, the geographic specificity of carrots and cabbage, both highland vegetables predominantly produced in Benguet and Bukidnon, do not translate to higher tradability. A possible explanation could be that Philippine household consumption of some vegetables such as cabbages are highly elastic at 1.9, compared to others such as tomatoes at 0.78 (Mutuc, Pan, and Rejesus 2007).

Grains are widely produced throughout the country and extensively traded at the same time. They comprise close to $80 \%$ of the volume traded among the 14 products, but nonetheless exhibit substantial border effects. But the border effects can also be said to be lower than expected given the bulky and low value nature of grains and cereals. Nonetheless, three aspects may counter the transport cost effect. First, they are staples. This is most apparent in the case of rice where the government's rice buffer stocking system directs about $5 \%$ of rice trade flows (NFA 2017). Second, cassava and corn are 
also main feed ingredients for the livestock and poultry sectors. Finally, they generally require lesser degree of specialized handling and storage.

Differences in product characteristics imply that the RRTS can affect trade frictions across products heterogeneously. We explore this by letting $\operatorname{Smprov}_{i j}$ vary by product and RRTS connection status:

$$
\begin{aligned}
& X_{i j, t}^{k}=\exp \left[\beta_{1} \text { lnDist }_{i j}+\beta_{2} \text { Lang }_{i j}+\beta_{3} \text { Land }_{i j}+\psi_{k} \text { Smprov }_{i j} \times \delta^{k}+\right. \\
& \left.\gamma_{k, R R T S} \operatorname{RRTS}_{i, R R T S} \times \operatorname{Smprov}_{i j} \times \delta^{k}+\eta_{i, t}+\theta_{j, t}+\delta_{k, t}+\epsilon_{i j, t}^{k}\right]
\end{aligned}
$$

The border estimates by product are shown in Figure 7. Products that are grown in specific provinces, such as onions and potatoes, benefited the most from the RRTS. In particular, the RRTS obliterated the border effect on potatoes, leading to a negative border effect. This means that on average, potatoes are traded more with other provinces than within the provinces that produce them. Bananas and pineapples, with their highly perishable nature also exhibited considerable reductions. Rice and corn also show modest reductions in border effects with the RRTS. However, the RRTS impact on the border effects of other products are negligible. Detailed results on the covariates are reported in the first column of Appendix Table A.6.

\section{(2) Varying across Time}

To track the evolution of border effects across time, $\operatorname{Smprov}_{i j}$ is interacted with year indicators, $\operatorname{Smprov}_{i j} \times Y r_{t} . Y_{t}$ is a dummy variable for each of the 15 years in the dataset. The results are illustrated in Figure 8, which suggests that border effects have been stable over time with possible modest declines. ${ }^{9}$ The sudden increase in border effect is noticeable for 2006 and coincides with a sudden 15\% increase in cargo handling charges after having been unchanged for the previous 4 years (ADB 2010). However, the confidence intervals suggest that the border effect in 2014 may not necessarily be different from the starting point in 2000.

The growing network of RRTS should translate to greater dampening of border frictions over time. We investigate this by letting $\operatorname{Smprov}_{i j}$ vary by RRTS linkage status and year.

$$
\begin{aligned}
& X_{i j, t}^{k}=\exp \left[\beta_{1} \text { lnDist }_{i j}+\beta_{2} \text { Lang }_{i j}+\beta_{3} \text { Land }_{i j}+\psi_{t} \text { Smprov }_{i j} x Y r_{t}+\right. \\
& \left.\gamma_{t, R R T S} \text { RRTS }_{i, R R T S} \times \text { Smprov }_{i j} \times Y r_{t}+\eta_{i, t}+\theta_{j, t}+\delta_{k, t}+\epsilon_{i j, t}^{k}\right]
\end{aligned}
$$

Figure 9 shows that RRTS is associated with a reduction of border effects for most years. However, the reduction is not continuous and cumulative as one would expect given the expanding RRTS network over time. The largest reductions are in 2009 and 2010, which coincide with the creation of several RRTS links with Cebu. See Appendix Table A.6, column 2 for details.

9 Gravity covariate estimates are in Appendix Table A.5. We abstract from discussions on the seasonality of trade in using annual aggregated data. Broader seasonal trends that may span years are accounted for by year-varying fixed effects interacted with province and product dummies. 
Figure 7: Reduction of Border Effects from Roll-On Roll-Off Terminal System by Product

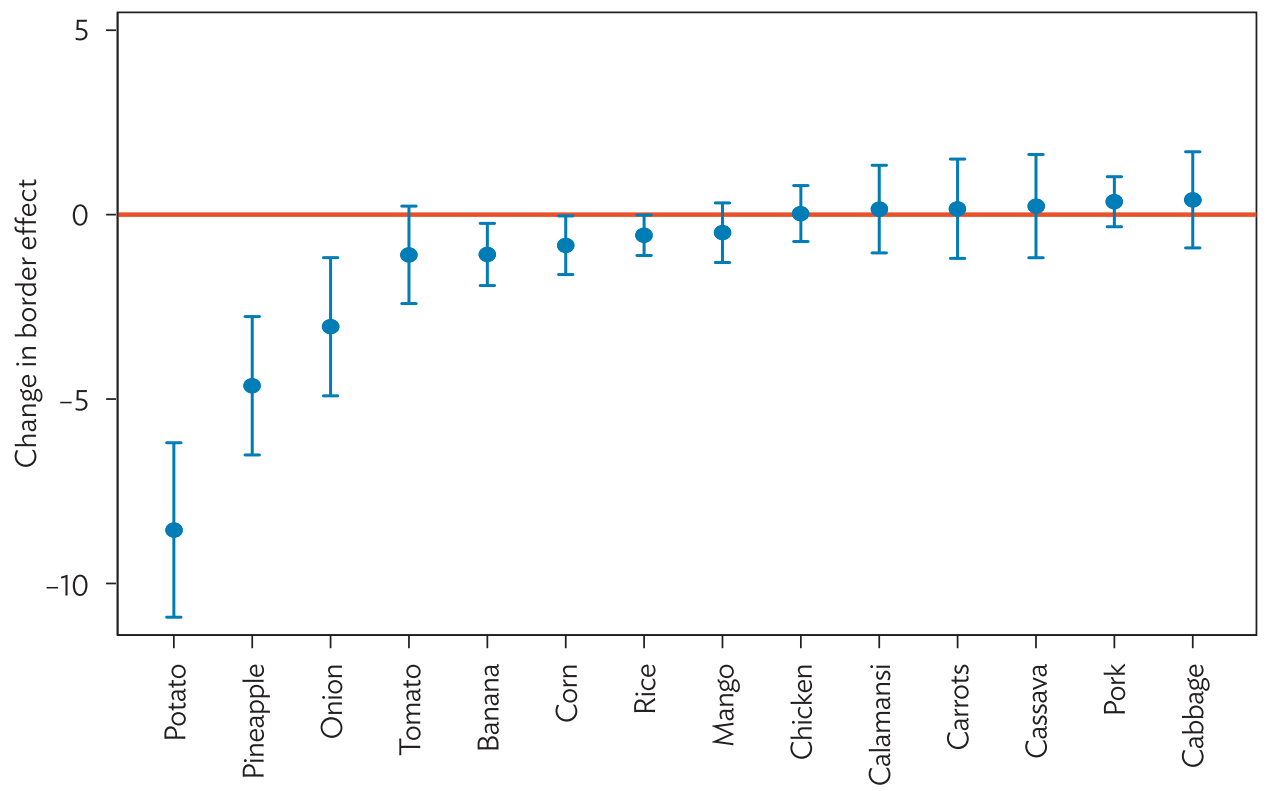

Note: Whiskers represent confidence intervals at $95 \%$.

Source: Author.

Figure 8: Border Effects over Time

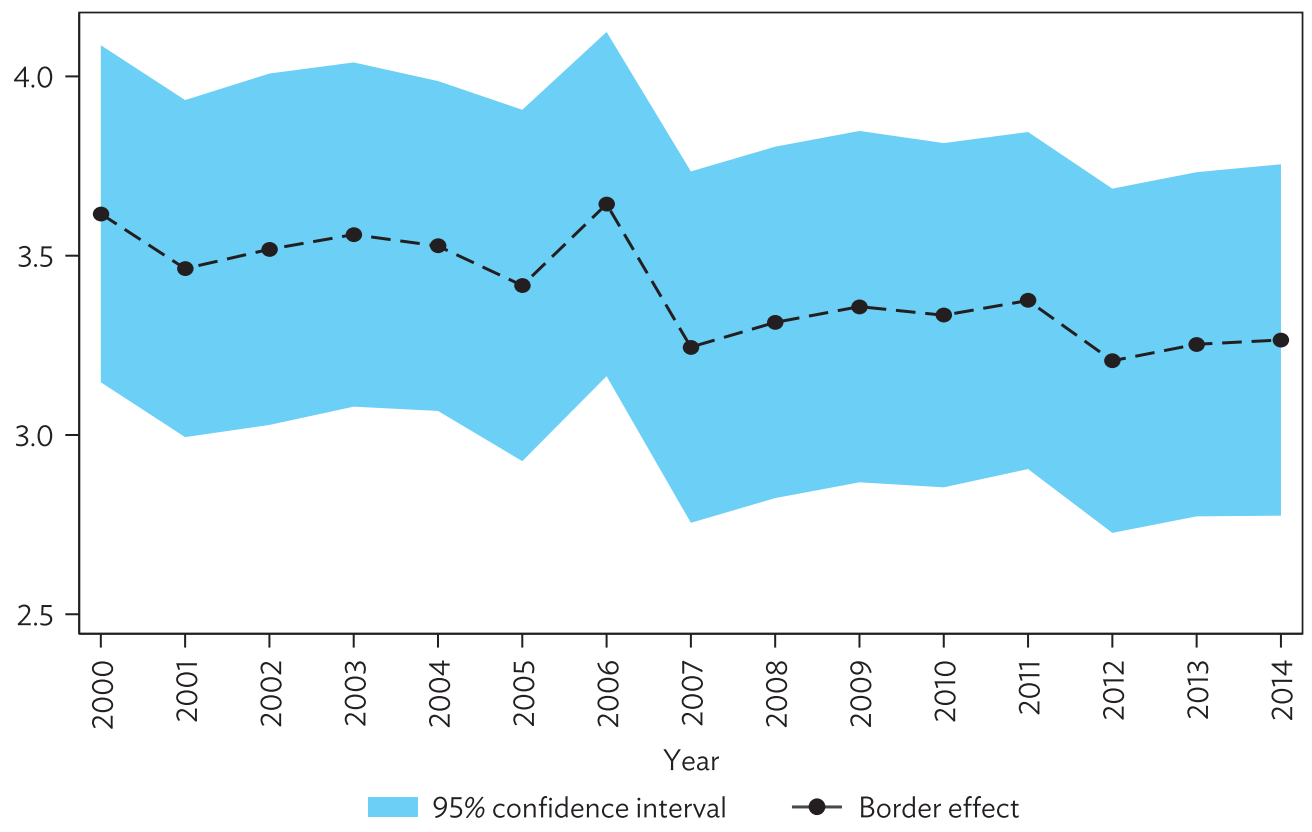

Source: Author. 
Figure 9: Reduction of Border Effects from Roll-On Roll-Off Terminal System over Time

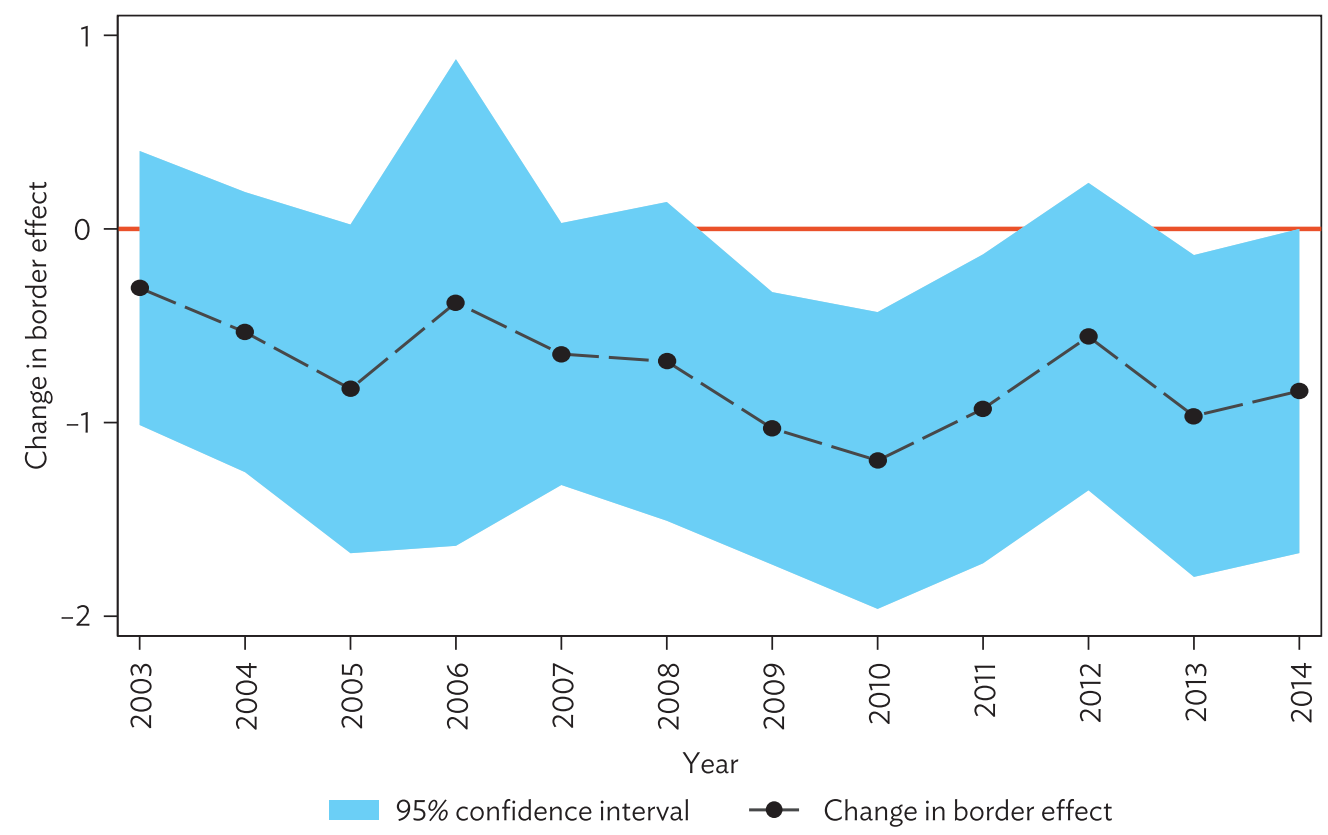

Source: Author

\section{(3) Varying by Province}

Province-specific border effects are estimated by letting $S_{m p r o v}$ vary by exporting province, $\operatorname{Smprov}_{i j} x \eta_{i}$, where $\eta_{i}$ is a set of dummies for the 60 provinces in the dataset. Figure 10 visualizes the estimated border effects for 54 out of 60 exporting provinces that can be retrieved. Gravity covariates are reported in column (3) of Appendix Table A.5, whereas border effect estimates behind the figure are in Appendix Table A.7.

Border effects vary widely across provinces. Darker shades represent higher borders, which tend to cluster in the Eastern seaboard. These are some of the poorest provinces in the Philippines that are also geographically remote from major economic regions. They also tend to be where hurricanes forming in the Pacific Ocean frequently make their first landfalls.

Except for Batangas, provinces with large ports indicated by a triangle in the figure have zero or negative province borders-Cagayan de Oro in Misamis Oriental, and Cebu. The significant border estimate for Batangas despite its major port operations can be explained by several factors. First, it has a large population which consumes most of its own production. In fact, it is a net importer of 12 out the 14 products considered in this study. Second, the products in the dataset comprise a small fraction of its outbound cargo operations - roughly 1\% in 2000, increasing to 5\% in 2014 (PPA 2017). In contrast, the figures for Cagayan de Oro are $7 \%$ and $25 \%$ respectively.

Provinces along the three vertical trunks do not necessarily have lower border effects. A possible exception is the Western trunk although the southern end of the link in Zamboanga del Norte 
has a high border estimate. On the other hand, Sorsogon, the northern tip of the central and eastern trunks, exhibits a high border effect.

Some provinces around the NCR in Central and Southern Luzon have moderate but significant trade frictions. This may at first be surprising given their proximity to a large market. However, while they are large producers and exporters, these regions are also considerable markets in themselves with high urban populations and light industry manufacturing firms that have a large consumer base. Southern Luzon, in particular, is the most populous region of the country (PSA 2015).

An examination of the correlation between the log of provincial land area size and province border effects suggest that the spatial attenuation bias as described by Coughlin and Novy (2016) is not a primary concern.

The impact of the RRTS on the border effect of each province is estimated by varying Smprov $_{i j}$ by province and RRTS linkage status.

$$
\begin{aligned}
& X_{i j, t}^{k}=\exp \left[\beta_{1} \text { lnDist }_{i j}+\beta_{2} \text { Lang }_{i j}+\beta_{3} \text { Land }_{i j}+\psi_{i} \text { Smprov }_{i j} \times \eta_{i}+\right. \\
& \left.\gamma_{i, R R T S} \operatorname{RRTS}_{i, R R T S} \times \text { Smprov }_{i j} \times \eta_{i}+\eta_{i, t}+\theta_{j, t}+\delta_{k, t}+\epsilon_{i j, t}^{k}\right]
\end{aligned}
$$

The change for each province-increased, decreased, no change-is presented in Figure 11. The estimate for each province is presented in Appendix Table A.8.

RRTS had heterogeneous effects on border frictions of provinces. Batangas, Occidental and Oriental Mindoro, colored in green, reduced their border effects significantly. The same is true for Marinduque even though its border friction was negligible even prior to the RRTS. All four provinces are geographically proximate and linked by RRTS with each other. They are also near the NCR.

Nonetheless, there are also provinces for which the RRTS heightened border frictions. The increases are largest for Basilan (+3.6), Sorsogon (+3.2), and Tawi-Tawi (+3.2). Albeit being linked by RRTS to Bohol, Cebu, and Misamis Oriental, the small island of Camiguin (+2.9) heightened its border frictions. Nonetheless, the Camiguin-Cebu RORO service only operates once a week, and that of Bohol-Camiguin once a day. As suggested by JICA (2007), frequency of service is key to benefiting from the RRTS.

At the same time, it is notable that the RRTS linked group of provinces in the southwestern extremities of the Philippines-Basilan, Sulu, Tawi-Tawi, and Zamboanga del Sur-all heightened their border effects after RRTS linkage, suggesting a possible crowding out of exports in regions that are less well connected to the major sea ports such as Cagayan de Oro and Cebu. 
Figure 10: Province Border Effects

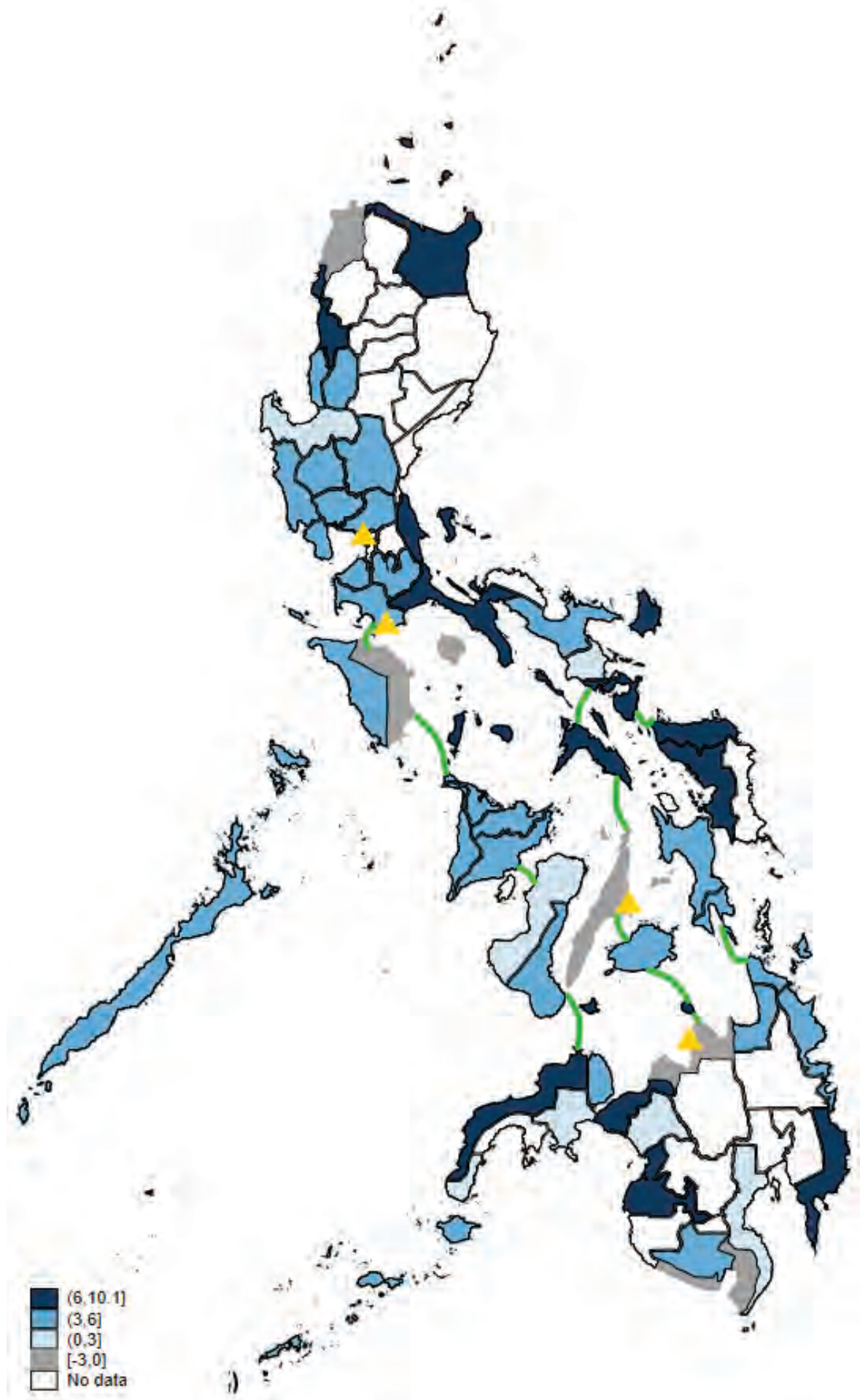


Figure 11: Change in Border Effects from RRTS, by Province

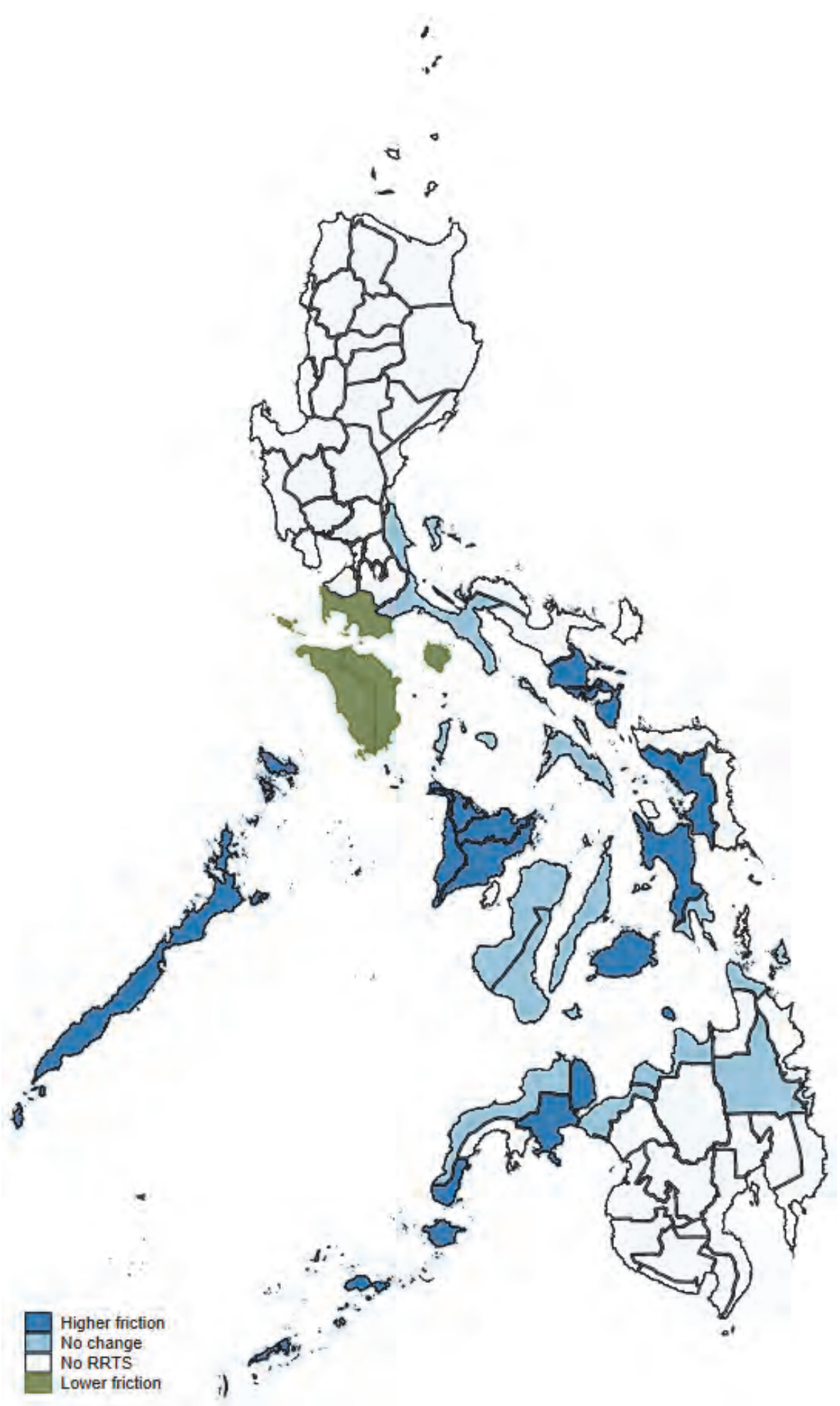

RRTS = Roll-On Roll Off Terminal System . 
The uneven contributions of the RRTS in province border effect reduction may be indicative of intensifying geographic concentration of trade activities. Provinces that reduced border effects are concentrated near the NCR. The welfare implications of these results are worthy of a separate indepth empirical inquiry.

However, there are some limitations to our methodology. First, we estimated export-oriented border effects. Suppose for example that the RRTS caused Cebu's exports to Leyte to increase, but not vice versa. Cebu will appear as having lowered border frictions, while Leyte's may not change or even increase if its production increases, but it remains a deficit province. This is a potential explanation for the intensification of border effects for Albay, Bohol, and Leyte.

Second, we abstract from connectivity issues within a province. This can affect our estimates of border effects in several ways. A province may appear to be heightening its border effects if municipalities within a province are becoming better connected with each other by land, and this is developing faster than the improvement of maritime links with other provinces. The other side of this scenario is that provinces may be too broad as a unit of observation if road networks within a province are not good, such that the benefits of the RRTS are only confined to the municipality linked by RRTS, but do not trickle through to the rest of the province.

Finally, RRTS can potentially increase border estimates if it improves connectivity within a province given that some provinces comprise of several islands. Nonetheless, an examination of maritime trade within a province suggest this mechanism can be ruled out.

\section{CONCLUSIONS AND POLICY IMPLICATIONS}

The Government of the Philippines established the RRTS with the aim of bringing down domestic maritime trade cost in the country.

Estimated border effects suggest that conditional on distance and province characteristics, provinces in the Philippines trade 28-53 times more with themselves than with other provinces. The introduction of the RRTS reduced this home bias tendency by 35-36 percentage points, equivalent to a factor of 0.64-65. This has been confirmed with findings that link RRTS to enhanced interprovincial maritime trade flows of agricultural products. Province pairs that are connected by RRTS trade 36\%$42 \%$ more compared to similar province pairs that do not have access to the infrastructure. This does not stem from displacing trade from provinces without RRTS connection.

A closer examination reveals heterogeneity in the distribution of border effects along the dimension of product and provinces. This pattern is likely due to a mixture of product characteristics having to do with geographic specificity in production and income elasticity of demand. Majority of the products in the study saw a decline in border effects following the introduction of the RRTS. In particular, the border effect practically disappeared for onions and potatoes-products that exhibit geographic specificity in production.

Estimated province border effects are lowest for major trading provinces such as Cebu and Misamis Oriental (Cagayan de Oro), and highest for many provinces that are remote from the main economic centers of their respective regions. 
The introduction of the RRTS decidedly reduced the border effects for a few provinces that are near the NCR, such as Batangas, Marinduque, and Occidental and Oriental Mindoro. However, it did not change the border effects for most of the provinces. Instead, remoter provinces in Southwest Mindanao heightened their frictions relative to other provinces. This combination of results suggests a possibility of a relative crowding out of trading activities in provinces that are remote from big demand centers.

To the best of our knowledge, this is the first empirical evaluation of the effects of RRTS on trade costs made possible by our new dataset. The historical dataset on the starting date of RORO services and the retrieval of intraprovince trade flows form part of our contribution to the literature. 


\section{REFERENCES}

Agnosteva, Delina E., James E. Anderson, and Yoto Yotov. 2015. "Intranational Trade Costs: Assaying Regional Frictions.” European Economic Review 112: 32-50.

Andales, Silvestre, and M. Gragasin. 2000. "Priorities and Constraints of Postharvest Technology in the Philippines." The $5^{\text {th }}$ JIRCAS International Symposium: Postharvest Technology in Asia.

Anderson, James E., Ingo Borchert, Aaditya Mattoo, and Yoto Yotov. 2018. "Dark Costs, Missing Data: Shedding Some Light on Services Trade.” European Economic Review 105: 193-214.

Anderson, James E., and Eric Van Wincoop. 2004. "Trade Costs.” Journal of Economic Literature 42 (3): 691-751.

Anderson, James E., and Yoto Yotov. 2010. "The Changing Incidence of Geography." American Economic Review 100: 2157-86.

Arvis, Jean Francois, Yann Duval, Ben Shepherd, Chorthip Utoktham, and Anasuya Raj. 2016. "Trade Costs in the Developing World: 1996-2010." World Trade Review 15 (3): 451-74.

Asian Development Bank (ADB). 2010. Bridges across Oceans: Initial Impact Assessment of the Philippines Nautical Highway System and Lessons for Southeast Asia. Manila.

Atkin, David, and Dave Donaldson. 2019. "Who's Getting Globalized? The Size and Implications of Intra-national Trade Costs." Econometrica, forthcoming.

Austria, Myrna S. 2002. "Philippine Domestic Shipping Industry: State of Competition and Market Structure.” Philippine Institute for Development Studies, PASCN Discussion Paper (2002-04).

Baier, Scott L., and Jeffrey H. Bergstrand. 2007. "Do Free Trade Agreements Actually Increase Members' International Trade?” Journal of International Economics 71 (1): 72-95.

Bangko Sentral ng Pilipinas. 2016. "Peso and USD Average Exchange Rate." http://www.bsp.gov.ph/statistics/statpage01.asp (accessed on 10 September 2016).

2018. “Peso and USD Average Exchange Rate.” http://www.bsp.gov.ph/PXWeb2007/database/ SPEI/ext_accts/exchange_en.asp (accessed 23 March 2018).

Basilio, Enrico L. 2008. Linking the Philippine Islands through Highways of the Sea. Pasig City, Philippines: Center for Research and Communication.

Bureau of Animal Industry (BAI). 2015. "OIE Declares Philippines Free from FMS and PPR." BAIDepartment of Agriculture. http://www.bai.gov.ph/old/index.php/regulatory/item/377-oiedeclares-philippines-free-from-fmd-and-ppr.

Coughlin, Cletus C., and Dennis Novy. 2013. "Is the International Border Effect Larger than the Domestic Border Effect? Evidence from US Trade." CESifo Economic Studies 59 (2): 249-76. 
2016. "Estimating Border Effects: The Impact of Spatial Aggregation." Federal Reserve Bank of St. Louis, Working Papers 2016 (006).

DIVA-GIS. Philippines Administrative Areas. DIVA-GIS 7.4. https://www.diva-gis.org/download (accessed 17 September 2016).

Eaton, Jonathan, and Samuel Kortum. 2002. "Technology, Geography, and Trade.” Econometrica 70 (5): 1741-79.

Eaton, Jonathan, Samuel Kortum, and Brent Neiman. 2015. "Obstfeld and Rogoff's International Macro Puzzles: A Quantitative Assessment." Journal of Economic Dynamics and Control 72: 523.

Fackler, Paul, and Barry Goodwin. 2001. "Spatial Price Analysis." In Handbook of Agricultural Economics 1B. Elsevier.

Fally, Thibault, Rodrigo Paillacar, and Cristina Terra. 2010. "Economic Geography and Wages in Brazil: Evidence from Micro-data.” Journal of Development Economics 91 (1): 155-68.

Faustino, Jaime, and Jon Morales. 2010. "Philippines Spearheads ASEAN Effort to Establish Regional RO-RO Sea Transport Network." The Asia Foundation. 22 September. https://asiafoundation.org/2010/09/22/philippines-spearheads-asean-effort-to-establishregional-ro-ro-sea-transport-network/.

Havranek, Tomas, and Zuzana Irsova. 2017. "Do Borders Really Slash Trade? A Meta-Analysis." IMF Economic Review 65 (2): 365-96.

Head, Keith, and Thierry Mayer. 2013. "Gravity Equations: Workhorse, Toolkit, and Cookbook." In Handbook of International Economics 4. Elsevier.

Hillberry, Russel, and David Hummels. 2003. "Intranational Home Bias: Some Explanations.” Review of Economics and Statistics 85 (4): 1089-92.

Hummels, David, and Vladimir Lugovskyy. 2006. "Are Matched Partner Trade Statistics a Usable Measure of Transportation Costs?” Review of International Economics 14 (1): 69-86.

Jacks, David S., Christopher M. Meissner, and Dennis Novy. 2008. "Trade Costs, 1870-2000." American Economic Review 98 (2): 529-34.

Japan International Cooperation Agency (JICA). 1992. "Nationwide Roll-on Roll-off Transport System Development Study in the Republic of the Philippines." JICA Report. 2007. "The Feasibility Study on the Development of Road RO-RO Terminal System for Mobility Enhancement in the Republic of the Philippines." JICA Report.

Llanto, Gilbert M., Enrico L. Basilio, and Leilanie Q. Basilio. 2005. "Competition Policy and Regulation in Ports and Shipping." Discussion Paper Series No. 2005-02. Philippine Institute for Development Studies. 
Llanto, Gilberto M., and Adoracion M. Navarro. 2014. "Relaxing the Cabotage Restrictions in Maritime Transport." Mimeo submitted to the Senate Committee on Trade, Commerce and Entrepreneurship, 9 January 2014 as comments to Senate Bill No. 1359 - An Act Allowing Foreign Vessels to Engage in Coastwise Trade in the Country and for Other Purposes.

McCallum, John. 1995. "National Borders Matter: Canada-U.S. Regional Trade Patterns." American Economic Review 85 (3): 615-23.

Mutuc, Maria Erlinda, Suwen Pan, and Roderick M. Rejesus. 2007. "Household Vegetable Demand in the Philippines: Is There an Urban-Rural Divide?” Agribusiness 23 (4): 511-27.

National Food Authority (NFA). 2017. "NFA Statistics on Rice Distribution." http://nfa.gov.ph/programs-projects/others/statistics (accessed 18 July 2016).

Philippine Ports Authority (PPA). 2017. "Port Statistics." http://www.ppa.com.ph/?q=content/statistics-1 (accessed 22 June 2016).

Philippine Statistical Authority. 2000. "2000 Census of Population and Housing.” Manila.

2015. "Population of the Philippines." http://openstat.psa.gov.ph/Database/Population-andMigration (accessed 27 October 2016).

2016. "Subnational Production and Consumption Data of Agricultural Products." CountrySTAT Philippines. http://openstat.psa.gov.ph/Database/Agriculture-Forestry-Fisheries (accessed 21 July 2016).

2017a. Domestic Coastwise Trade Data. Manila.

2017b. "Technical Notes on National Agricultural Statistics." CountrySTAT Philippines: http://openstat.psa.gov.ph/Featured/CountrySTAT-Philippines (accessed 18 September 2016).

Santos Silva, João, and Silvana Tenreyro. 2006. "The Log of Gravity.” Review of Economics and Statistics 88 (4): 641-58.

United States Agency for International Development (USAID). 1994. Liner Shipping Route Study.

2014. “USAID’s Growth with Equity in Mindanao Program: GEM.” Completion Report January 2008 to December 2013.

Wolf, Holger C. 2000. "Intranational Home Bias in Trade." The Review of Economics and Statistics 82 (4): 555-63. 


\section{Over Land and Over Sea \\ Domestic Trade Frictions in the Philippines}

This paper estimates domestic trade cost in the Philippines and evaluates how the Roll-On Roll-Off Terminal System (RRTS) affected its evolution using the concept of "border effects." Domestic trade costs are found to be substantial in the Philippines such that provinces trade 25-53 times more with themselves than with other provinces. The RRTS reduced this "home bias" tendency by a factor of $0.64-0.65$. However, this reduction is unevenly distributed. Provinces closest to the capital account for most of the border effect attenuation.

\section{About the Asian Development Bank}

ADB is committed to achieving a prosperous, inclusive, resilient, and sustainable Asia and the Pacific, while sustaining its efforts to eradicate extreme poverty. Established in 1966, it is owned by 68 members -49 from the region. Its main instruments for helping its developing member countries are policy dialogue, loans, equity investments, guarantees, grants, and technical assistance. 